DEMOGRAPHIC RESEARCH

VOLUME 36, ARTICLE 56, PAGES 1721-1758

PUBLISHED 31 MAY 2017

http://www.demographic-research.org/Volumes/Vol36/56/

DOI: 10.4054/DemRes.2017.36.56

Research Article

\title{
The mental health of youth and young adults during the transition to adulthood in Egypt
}

Jenny Liu

Sepideh Modrek

Maia Sieverding

(C) 2017 Jenny Liu, Sepideh Modrek \& Maia Sieverding.

This open-access work is published under the terms of the Creative Commons Attribution NonCommercial License 2.0 Germany, which permits use, reproduction \& distribution in any medium for non-commercial purposes, provided the original author(s) and source are given credit.

See http:// creativecommons.org/licenses/by-nc/2.0/de/ 


\section{Contents}

1 Introduction 1722

1.1 Demographic change and the transition to adulthood in MENA 1724

1.2 Mental health among young people in MENA 1727

1.3 Aims of this paper 1728

2 Methods 1728

$\begin{array}{lll}2.1 & \text { Data } & 1728\end{array}$



$\begin{array}{lll}2.3 & \text { Statistical analysis } & 1732\end{array}$

3 Results 1737

$\begin{array}{lll}3.1 & \text { Sample characteristics } & 1737\end{array}$

3.2 Mental health status 1738

3.3 Sociodemographic predictors of mental health status 1739

3.4 Associations of key life transitions with changes in mental health 1741

4 Discussion 1742

4.1 Main findings 1742

$\begin{array}{ll}4.2 & 1746\end{array}$

$\begin{array}{lll}5 & \text { Conclusion } & 1747\end{array}$

$\begin{array}{llr}6 & 1748\end{array}$

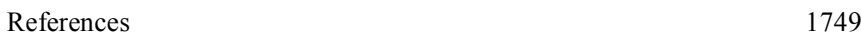




\title{
The mental health of youth and young adults during the transition to adulthood in Egypt
}

\author{
Jenny Liu ${ }^{1}$ \\ Sepideh Modrek ${ }^{2}$ \\ Maia Sieverding ${ }^{3}$
}

\begin{abstract}
BACKGROUND

There has been growing interest in the stalled transition to adulthood in the Middle East and North Africa (MENA) and its consequences for young people's socioeconomic outcomes. However, little is known about how important life transitions relate to youth psychosocial well-being in the region.
\end{abstract}

\section{OBJECTIVE}

Drawing on a life course framework, we estimate the associations between making transitions in education, employment, and marriage with changes in mental health among young people in Egypt.

\section{METHODS}

We descriptively analyze mental health scores, measured via the Self-Reporting Questionnaire-20 and disaggregated by gender, for a panel of young people first surveyed in 2009 at ages 13-29 and followed up in late 2013 and early 2014 . We regress change in mental health scores against indicators of making different transitions.

\section{RESULTS}

Young women experience worse mental health than young men overall. Lower school achievement was associated with poorer mental health; being out of the labor force was an additional risk factor for young men. While average mental health scores improved over time, over a quarter of the sample experienced worsening mental health, related to failure to marry and find a job among older men, and failure to finish schooling among younger women.

${ }^{1}$ Department of Social and Behavioral Sciences, Institute for Health and Aging, School of Nursing, University of California, San Francisco (UCSF), San Francisco, USA. E-Mail: Jenny.Liu2@ucsf.edu.

${ }^{2}$ Health Equity Institute, San Francisco State University, San Francisco, USA.

${ }^{3}$ Faculty of Health Sciences, American University of Beirut, Beirut, Lebanon. 


\section{CONCLUSIONS}

Mental health is an important but often overlooked component of youth well-being during the transition to adulthood in MENA, and potentially other low- and middleincome countries.

\section{CONTRIBUTION}

This is the first paper to empirically examine the relationship between psychosocial well-being and achieving important socioeconomic milestones among a nationally representative cohort of young people in MENA.

\section{Introduction}

The transition from adolescence to adulthood is a period of life during which individuals experience far-reaching changes in their social and economic roles in society, and undergo significant psychological and physical development (Hogan and Astone 1986). The linkages between these changes have been theorized by life course scholars through a focus on age grading; as biological age marks different stages in human development, 'social age' denotes expected roles and transitions at various periods of life (Elder and Rockwell 1979; Hogan and Astone 1986). In life course theory, the transition to adulthood is thus conceived of as a process - a period of life during which individuals pass through multiple, often closely sequenced age-graded experiences and expectations. These age-graded expectations are influenced both by institutions, such as the school system, which specifies expected ages for entry and exit, and by social norms. Norms around expected ages for transitions, such as marriage, as well as the sequencing of transitions (e.g., having children prior to marriage, or continuing schooling after marriage) vary substantially across societies and subpopulations defined by gender, ethnicity, religion, and other factors, as well as over time within the same society or group. The rigidity of expectations around the transition to adulthood also varies considerably across contexts, both in the extent to which institutions allow flexibility around age-structured services or benefits, and in the extent to which nonnormative pathways through the transition to adulthood are socially sanctioned (Hogan and Astone 1986; Shanahan 2000).

A wide literature from the United States and other Western contexts has examined the interplay of social, economic, and psychological outcomes during the transition to adulthood. Although most life course scholars agree that social norms and institutions play an important role in age grading, it is also the case that there is considerable variability in young people's pathways through the transition to adulthood. The 
literature on the relationship between socioeconomic and psychological outcomes during the transition to adulthood has often focused on this variability, as it is affected by both individual characteristics and social or economic constraints. For instance, scholars have examined how young people's agency, aspirations, and other psychological factors influence their pathways through the transition to adulthood. Conversely, how youth cope during the transition to adulthood with stressors such as the timing, sequencing, or failure to complete expected socioeconomic transitions may affect their psychosocial outcomes. ${ }^{4}$ This literature also points to the importance of period effects, or how the particular historical circumstances during which a cohort is aging, affect the opportunities and institutions that influence pathways through the transition to adulthood (Elder and Rockwell 1979; Hogan and Astone 1986; Shanahan 2000).

The present historical and institutional context for the transition to adulthood in the Middle East and North Africa (MENA) region has become a subject of substantial popular and academic debate given recent unrest in the region. Young people's disillusionment and frustration with lack of economic opportunity and declining social mobility has been cited as one driver of the Arab Spring (Campante and Chor 2012). This argument builds on a larger literature dedicated to the phenomenon of 'waithood' in MENA, a period of delayed transition to full adulthood as young people struggle to attain relevant education, obtain a good job, and meet the financial requirements of forming a family (Dhillon and Yousef 2009). ${ }^{5}$ Although a wide literature has addressed the challenges that young people face in their transitions from education to work and marriage in MENA (Amer 2014, 2015; Assaad, Binzel, and Gadallah 2010; Dhillon and Yousef 2009; Roushdy and Selwaness 2015; Salem 2016; Singerman 2007), this literature has focused almost exclusively on socioeconomic outcomes and has engaged little, if at all, with the developmental aspects of the transition to adulthood and life course theory. Very little is known about young people's psychosocial well-being within the context of delayed transitions to adulthood in the region.

The lack of attention to broader health and well-being is an important gap in our understanding of the transition to adulthood in MENA because young people's pathways through this period of life have long-term implications for a range of health and socioeconomic outcomes. Young people's current choices will largely determine their later life outcomes, which, under the right circumstances and with the necessary

\footnotetext{
${ }^{4}$ For a review of this literature, see Hogan and Astone (1986) and Shanahan (2000).

${ }^{5}$ We follow the United Nations Department of Economic and Social Affairs (UNDESA) in defining 'youth' as ages 15-24 (UNDESA n.d.). However, in research on the transition to adulthood in MENA, older ages are often included - up to age 29 or 35 - due to the phenomenon of delayed transitions to work and marriage in the region (Amer 2009; Assaad, Binzel, and Gadallah 2010; Assaad and Levison 2017; Dhillon and Yousef 2009; Roushdy and Sieverding 2015). We refer to this older age group from 25-35 as 'young adults' and the full age range from $15-35$ as 'young people.'
} 
investments, could ultimately yield large economy-wide returns. However, international literature has demonstrated that the inability to achieve the ideal life course can negatively affect psychosocial well-being (Hardie 2014; Pisarik and Shoffner 2009; Reynolds and Baird 2010; Vuolo, Staff, and Mortimer 2012), which can further lead young people to invest less in critical human capital assets, including education and health. While much is known about the psychosocial well-being of young people over the transition to adulthood in high-income countries, little is known about these dynamics in the MENA region, or in other low- and middle-income contexts.

In this paper we use a unique, nationally representative dataset from Egypt to examine the mental health status of a cohort of young men and women who have experienced increasing uncertainty in recent years, including two regime changes, ongoing sociopolitical unrest, and economic stagnation. As defined by the World Health Organization (WHO), mental health is "a state of well-being in which every individual realizes his or her own potential, can cope with the normal stresses of life, can work productively and fruitfully, and is able to make a contribution to her or his community" (World Health Organization 2014). In particular, we examine the sociodemographic correlates of mental health well-being, as measured by the WHOvalidated 20-item Self-Reporting Questionnaire-20 (SRQ-20) and its associations with making key life transitions in education, employment, and marriage.

\subsection{Demographic change and the transition to adulthood in MENA}

The countries of MENA - like many other low- and middle-income countries - have been experiencing a 'youth bulge,' or a demographic stage during which the proportion of the young population increases relative to other age groups. As these large cohorts of young people complete their education and transition into the labor market, they may produce a demographic dividend as the dependency ratio decreases. However, if the labor market is unable to absorb these young people, a variety of economic, social, and political stressors may ensue (Assaad and Roudi-Fahimi 2007; Goldstone 2002; RoudiFahimi and Kent 2007; Urdal 2006). In MENA, the youth bulge peaked in the early 2000 s, and the percentage of the working age population that is 15-24 has now declined to about $27 \%$ (about $17 \%$ of the total population) from a high of almost $35 \%$ ( $21 \%$ of the total population). This group constitutes approximately 80 million young people (Assaad and Levison 2017). In Egypt, the most populous country in the MENA region and the focus of this paper, approximately $34.5 \%$ of the population is between the ages of 15 and 34 (United Nations Department of Economic and Social Affairs, Population Division 2015). These young people are making the transition to adulthood, assuming 
new roles and responsibilities as they finish schooling, enter the labor force, marry, and start families.

However, the current generation of young people is passing through the transition to adulthood in a context that is very different from that of their parents. In postindependence societies throughout the Middle East, the transition to adulthood was heavily influenced by state institutions, as the public provision of education, social protection, and public-sector jobs expanded rapidly (Dhillon, Yousef, and Dyer 2009). Since the 1990s this expansion of the public sector has slowed as neoliberal economic policies have been implemented; yet young people, education systems, and the labor market have been slow to adjust to the new economic realities (Dhillon, Yousef, and Dyer 2009). The result has been a variety of negative labor market outcomes for young people, including the highest youth unemployment rates of any developing region in recent years, at nearly $30 \%$ in the Middle East and $24 \%$ in North Africa among youth aged 15-24 (Assaad and Levison 2017).

In Egypt, the postindependence social contract was characterized by free education through university level and a guarantee of public-sector employment for all graduates of secondary and postsecondary education regardless of gender (Assaad 1997, 2007). Beginning with the economic decline of the 1980s, however, the state-centered life course model proved increasingly unsustainable and the Egyptian government abandoned the policy of guaranteeing public employment to graduates (Assaad 2007). Nevertheless, the high value placed on advanced degrees led families to continue to invest in education, resulting in rapid increases in educational attainment among younger cohorts (Elbadawy 2015; Salehi-Isfahani, Hassine, and Assaad 2013). Yet with the public sector effectively closed to new entrants, the transition from school to work has increasingly become a problem of expectations-opportunities mismatch (Assaad 2008; Assaad and Barsoum 2009). Unemployment in Egypt is primarily a problem of youth entry into the labor market (Assaad 2008), with the youth (aged 15-29) unemployment rate at $9.3 \%$ for men and $32.3 \%$ for women in 2013 (Roushdy and Selwaness 2015). Large percentages of young people currently enter the labor market through the informal sector, where employment is more precarious and offers few legal protections (Amer 2015), despite that fact that employment aspirations remain heavily oriented towards government jobs (Barsoum 2015). This labor market failure has further affected young people's prospects for marriage and family formation, as saving for marriage - the main marker of achieving adult status - is increasingly challenging (Dhillon, Yousef, and Dyer 2009; Singerman 2007). Young people in Egypt are expected to set up a fully equipped, independent dwelling prior to marriage. The cost of this dwelling, combined with the bride's trousseau and celebrations, means that families spend an average of 61,200 Egyptian pounds on a marriage (Salem 2015), which was 
approximately three times annual GDP per capita in $2012 .{ }^{6}$ The bulk of these expenditures fall on young men and their natal families (Salem 2016).

Adding to the myriad institutional and economic challenges facing young people in Egypt today, the current generation of young people is also making the transition to adulthood in the midst of ongoing sociopolitical unrest. Mass popular protests in January 2011 marked the beginning of a period during which the country underwent two regime changes and experienced an overall increase in political unrest, including more frequent instances of violence. While political events have been concentrated in the capital, Cairo, the majority of governorates in 2013 had also experienced anywhere from $20-100$ such events, $15 \%$ of which resulted in fatalities. ${ }^{7}$ At the same time, lack of security and the economic crisis topped young people's list of priorities for the country in 2014, over issues related to political transition, demonstrating young people's continued insecurity about daily life (Ramadan and Sieverding 2015).

This context of uncertainty during the transition to adulthood has important implications for young people's long-term outcomes. From a psychological perspective, the numerous social role changes encompassed by the transition to adulthood may be expected to impact mental health outcomes as young people are exposed to contexts and experiences that differ from developmental influences during childhood (Schulenberg, Sameroff, and Cicchetti 2004). Uncertainty and the inability to successfully pursue planned or desired pathways during the transition to adulthood may influence the directionality of these impacts. Following life course theory, the disruption of individuals' progression through age-differentiated roles, and the delay of or failure to successfully complete certain socially or institutionally conditioned events (e.g., marriage, school-to-work transition), may lower overall well-being and lead to poorer life outcomes (Elder 1998; Hogan and Astone 1986; Shanahan 2000). Human capital investments central to life transitions may be especially at risk; as confidence in established routes of success deteriorates, young people may become despondent or experience more anxiety about their future prospects, which may further compromise their chances of achieving their goals (Sadler and Gupta 2014). Hence, understanding the sociodemographic correlates of psychosocial well-being, including those associated with making the key transitions into adulthood, is the first step to characterizing the impact of myriad demographic, social, political, and economic challenges on young people's development.

\footnotetext{
${ }^{6}$ Authors' calculations based on GDP per capita from World Development Indicators (World Bank 2016). Calculation of marriage costs in USD approximated using August 2012 exchange rate.

${ }^{7}$ Authors' calculations from the Armed Conflict Location and Event Data Project (Raleigh et al. 2010).
} 


\subsection{Mental health among young people in MENA}

The global burden of poor mental health, including among young people, has increasingly been recognized as a major public health issue (Lancet Global Mental Health Group 2007; Patel et al. 2014; Whiteford et al. 2013). Worldwide, young people are disproportionately affected by mental disorders and related risk behaviors (Whiteford et al. 2013), which are often not recognized or addressed until later in life (Patel et al. 2014). In addition to its consequences for young people's overall well-being and years lived free of disability, mental illness is associated with factors such as lower educational achievement, substance abuse, and poorer sexual and reproductive health (Patel et al. 2014). The global economic burden of mental illness, including individual costs of treatment and income loss, as well as economy-wide reductions in productivity, is substantial (Bloom et al. 2011).

Poor mental health is a key public health challenge in the MENA region. A 2010 study on the global burden of disease found that although major depressive disorder was the $11^{\text {th }}$ leading cause of disability adjusted life years (DALYs) globally, it was the third leading cause in the MENA region (Ferrari et al. 2013). Major depressive disorder was the leading cause of years of life lived with disability (YLDs) in the region, and was the first and second leading cause of YLDs among women and men, respectively. Likewise, anxiety disorder was the fourth and fifth leading cause of YLDs among women and men, respectively. Overall DALYs caused by major depressive disorder and anxiety peaked among the 20-29 age group (Mokdad et al. 2014).

There has been relatively little research on mental health in Egypt specifically that uses population-based samples aimed at understanding the burden of disease attributable to depressive and anxiety disorders, and the studies that do exist mostly focus on specific population groups and are not representative (Afifi 2006; El Kady and Ibrahim 2013; Ghanem et al. 2009; Kasemy et al. 2016; Moussa et al. 2015). To the best of our knowledge, the most recent large-scale study of mental health in Egypt was a survey of 14,640 individuals aged 18-64 in five governorates conducted in 2003 . The authors found that depressive and anxiety disorders were the most common form of mental disorder. ${ }^{8}$ Overall, $10.6 \%$ of men and $21.1 \%$ of women were found to have a mental disorder, but the authors did not examine patterns by age and the results were only representative of the selected regions (Ghanem et al. 2009).

\footnotetext{
${ }^{8}$ The authors carried out a preliminary survey as an initial step for the National Survey of Prevalence of Mental Disorders in Egypt. The stratified sample was taken from five governorates: Alexandria, Giza, Qaliubia, Fayoum, and Ismalia.
} 


\subsection{Aims of this paper}

In order to link this limited literature on young people's mental health in MENA to the literature on stalled transitions to adulthood in the region, our study has three aims. We first characterize the mental health status of youth and young adults in Egypt, including associations with sociodemographic predictors. Second, we assess changes in mental health status from 2009 to 2014 for a nationally representative panel of young people. Lastly, we describe the relationships between important life transitions in education, employment, and marriage with changes in mental health status. Understanding the mental health consequences of experiencing stalled transitions to adulthood provides us with insight into the levels of despondency and the sources of frustration felt among the current generation of Egyptian young people.

\section{Methods}

\subsection{Data}

The data for this study comes from the Survey of Young People in Egypt (SYPE), a nationally representative survey of over 15,000 young people aged 10-29 from 11,000 households first conducted in 2009 (Population Council 2010). In late 2013 and early 2014, a second wave of the SYPE was conducted which followed up on $73 \%$ of the 2009 sample, constituting one of the largest panels of young people in the MENA region (Roushdy and Sieverding 2015). In addition to household characteristics, the SYPE includes extensive modules on education, labor force participation, health, and family formation. Many of the same questions were asked in both waves, which enables us to analyze variables longitudinally and track key life transitions for each respondent. Although SYPE includes individuals aged 10-29, we limit our sample to individuals aged 13-29 in 2009 (aged $18-35^{9}$ in 2013/2014) who answered the mental health status module in both waves, as this is our primary outcome of interest. The restricted dataset contains 3,326 young men and 4,065 young women for analysis.

\footnotetext{
${ }^{9}$ Depending on the timing of the 2009 and 2013/2014 survey interviews, a small number of individuals experienced one more birthday. There were also cases of age misreporting, leading to inconsistencies in age across the two waves. We included in the sample all individuals who reported being age 18 or over in the 2013/2014 wave, as we cannot determine in which wave reported age is correct.
} 


\subsection{Mental health measures}

The SYPE included 20 WHO-validated questions to measure overall mental health status, the Self-Reporting Questionnaire-20 (SRQ-20). While other measures of mental or psychosocial well-being exist, the SRQ-20 was the only measure used in the SYPE. The SRQ-20 was designed to screen for psychiatric disturbance in primary health care settings, and especially for use in developing countries (Beusenberg and Orley 1994). It has been validated in multiple countries and languages. In survey research, it is often used as a proxy measure for mental health status, and can be either self- or intervieweradministered.

In the SRQ-20, each person is asked to respond yes or no to a series of 20 questions about experiencing different physical symptoms of psychiatric disturbance, feelings of nervousness, uncertainty, interest in daily activities, and sense of self-worth (see Table 1 for SRQ-20 component items). For each item we code a dummy variable for each positive response (i.e., yes $=1$; no $=0$ ), which indicates the self-reported presence of a poor mental health indicator. We then sum responses to all 20 items to create a continuous variable index ranging from 0 to 20 . Low values of the summary index represent relatively better mental health status (i.e., presence of fewer symptoms of psychiatric disturbance); conversely, higher scores represent relatively worse mental health status (i.e., presence of more symptoms of psychiatric disturbance). This continuous summary index is our main outcome of interest in our regression analyses. Recent studies suggest that scoring the SRQ-20 needs to take gender into account (Ghubash et al. 2001; Scholte et al. 2011). In the SYPE sample, SRQ-20 score distributions substantively differ by gender (see Figure 1). Thus, we stratify all analyses by gender. 
Liu, Modrek \& Sieverding: The mental health of young adults during the transition to adulthood in Egypt

\section{Table 1: $\quad$ Self-reporting questionnaire (SRQ-20) responses, Survey of Young} People in Egypt panel (2009, 2014)

\begin{tabular}{|c|c|c|c|c|c|}
\hline \multirow{2}{*}{\multicolumn{2}{|c|}{ SRQ-20 items }} & \multicolumn{2}{|c|}{ Men } & \multicolumn{2}{|c|}{ Women } \\
\hline & & 2009 & 2014 & 2009 & 2014 \\
\hline 1 & Do you often have headaches? & $25.3 \%$ & $19.2 \%$ & $47.9 \%$ & $24.8 \%$ \\
\hline 2 & Is your appetite poor? & $17.3 \%$ & $13.5 \%$ & $31.7 \%$ & $17.9 \%$ \\
\hline 3 & Do you sleep badly? & $15.5 \%$ & $16.7 \%$ & $32.7 \%$ & $20.9 \%$ \\
\hline 4 & Are you easily frightened? & $7.3 \%$ & $6.2 \%$ & $40.6 \%$ & $22.7 \%$ \\
\hline 5 & Do your hands shake? & $11.1 \%$ & $4.8 \%$ & $15.2 \%$ & $6.5 \%$ \\
\hline 6 & Do you feel nervous, tense, or worried? & $28.4 \%$ & $18.1 \%$ & $42.4 \%$ & $23.3 \%$ \\
\hline 7 & Is your digestion poor? & $9.0 \%$ & $6.2 \%$ & $21.7 \%$ & $9.4 \%$ \\
\hline 8 & Do you have trouble thinking clearly? & $17.5 \%$ & $10.5 \%$ & $26.7 \%$ & $16.5 \%$ \\
\hline 9 & Do you feel unhappy? & $17.1 \%$ & $8.6 \%$ & $23.9 \%$ & $12.2 \%$ \\
\hline 10 & Do you cry more than usual? & $4.1 \%$ & $3.1 \%$ & $22.8 \%$ & $13.3 \%$ \\
\hline 11 & Do you find it difficult to enjoy your daily activities? & $12.6 \%$ & $8.7 \%$ & $21.4 \%$ & $12.7 \%$ \\
\hline 12 & Do you find it difficult to make decisions? & $18.6 \%$ & $9.5 \%$ & $26.2 \%$ & $18.8 \%$ \\
\hline 13 & Are you unable to resume your daily work? & $7.1 \%$ & $5.0 \%$ & $17.5 \%$ & $9.1 \%$ \\
\hline 14 & Are you unable to play a useful part in life? & $8.0 \%$ & $5.7 \%$ & $17.6 \%$ & $8.5 \%$ \\
\hline 15 & Do you lose interest in things? & $8.8 \%$ & $9.1 \%$ & $14.6 \%$ & $12.8 \%$ \\
\hline 16 & Do you feel that you are a worthless person? & $3.1 \%$ & $4.7 \%$ & $11.2 \%$ & $6.8 \%$ \\
\hline 17 & Has the thought of committing suicide been on your mind? & $2.0 \%$ & $2.9 \%$ & $9.8 \%$ & $3.9 \%$ \\
\hline 18 & Do you feel tired all the time? & $5.7 \%$ & $4.9 \%$ & $22.7 \%$ & $9.4 \%$ \\
\hline 19 & Do you have uncomfortable feelings in your stomach? & $5.8 \%$ & $4.8 \%$ & $18.5 \%$ & $8.5 \%$ \\
\hline 20 & Are you easily tired? & $5.2 \%$ & $5.7 \%$ & $24.4 \%$ & $14.8 \%$ \\
\hline \multicolumn{6}{|c|}{ Summary measures } \\
\hline \multicolumn{2}{|c|}{ Summary index (range $0-20$ ) } & 2.29 & 1.68 & 4.90 & 2.73 \\
\hline \multicolumn{6}{|c|}{ Change in the summary index } \\
\hline \multicolumn{2}{|c|}{ Difference (2014-2009) } & & -0.61 & & -2.17 \\
\hline \multicolumn{2}{|c|}{ Improves } & & $43.4 \%$ & & $59.8 \%$ \\
\hline \multicolumn{2}{|c|}{ No change } & & $27.1 \%$ & & $12.4 \%$ \\
\hline \multicolumn{2}{|c|}{ Worsens } & & $29.5 \%$ & & $27.8 \%$ \\
\hline \multicolumn{2}{|c|}{ Poor mental health indicator (index $>=8$ ) } & $5.8 \%$ & $3.8 \%$ & $26.3 \%$ & $11.0 \%$ \\
\hline \multicolumn{2}{|l|}{$\mathrm{N}$} & \multicolumn{2}{|c|}{3,316} & \multicolumn{2}{|c|}{4,065} \\
\hline
\end{tabular}


Because we have two waves of SYPE data for the same cohort of individuals, we can examine the change in mental health status over time for each person. Therefore, in our main regression analyses (see Section 2.3), which seek to predict the change in mental health, we specify our main outcome as the difference in the summary index scores between waves (i.e., 2014 minus 2009). The resulting first-differenced SRQ-20 index ranges from -20 to +20 and approximates a normal distribution. In other words, if the index score remains the same in both waves, the difference is calculated as 0 , reflecting no change in the respondent's overall mental health. If the 2014 score is higher than the 2009 score, the difference will be positive and indicates a worsening of mental health status over time. Conversely, if the 2014 score is lower than the 2009 score, the resulting difference is negative, reflecting an improvement in mental health.

We use the continuous index score and the first-differenced change in the index score between waves as the main outcomes for all statistical analyses. To facilitate external comparison in descriptive analyses and for use in sensitivity analyses, we also convert the continuous index score into a dummy variable indicator for having poor mental health when the score is 8 or higher. This threshold was previously used to characterize the likely presence of a mental disorder, validated for an Egyptian population (Vizcarra et al. 2004), and has been used elsewhere to describe the prevalence of mental health disorders among adolescents and young adults (Population Council 2010). 


\section{Figure 1: Cumulative distribution of the mental health summary index by survey year and gender}

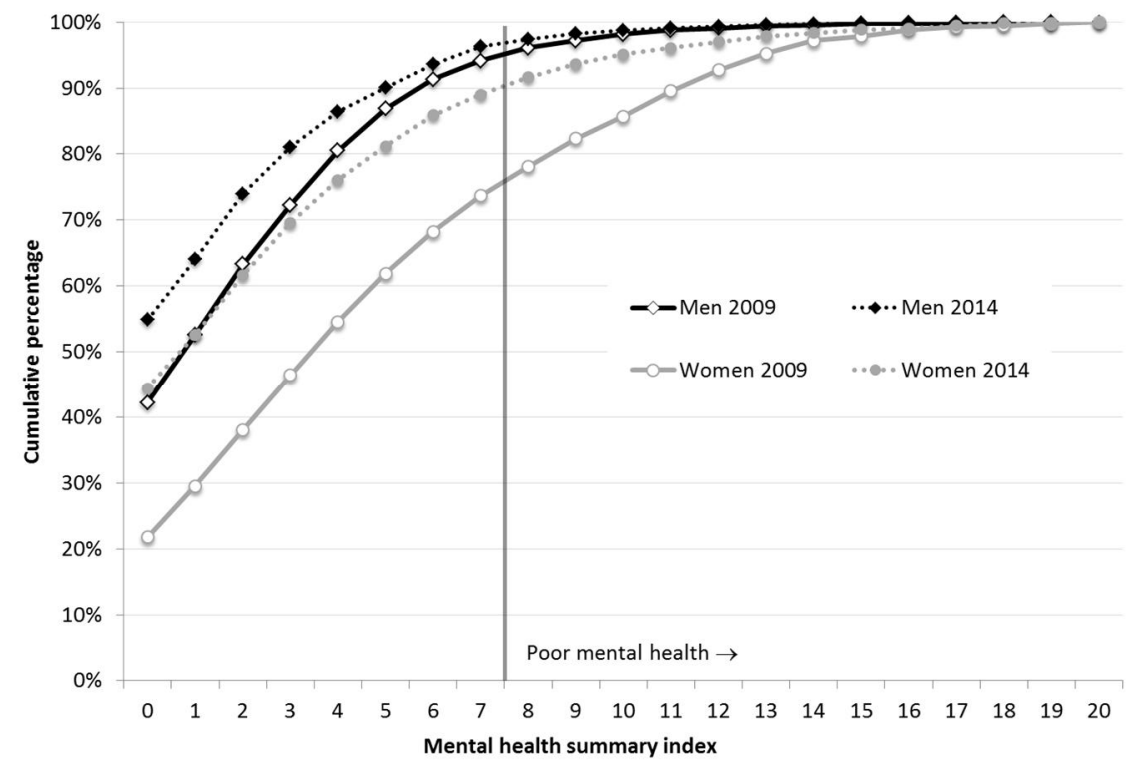

Notes: The cumulative probability distribution for young men in both waves lies everywhere to the left of the distribution for young women, indicating that young women have categorically worse mental health (i.e., higher mental health score). For example, in 2009, $94 \%$ of young men have a mental health score less than 8 , the threshold indicated for poor mental health, compared to only $74 \%$ of young women who score less than 8 . In other words, in $20096 \%$ and $26 \%$ of young men and women, respectively, have poor mental health. The distribution for men is also more concentrated, with a smaller variance as compared to a more dispersed distribution for women. Across waves, the cumulative probability distributions shift to the right for both men and women, illustrating the overall improvement in average mental health scores over time, a change that is relatively larger for women than it is for men even though women still show categorically worse mental health. In $2014,3.8 \%$ and $11.0 \%$ of young men and women, respectively, could be considered to have an index score that exceeds the poor mental health threshold.

\subsection{Statistical analysis}

We first present the sociodemographic characteristics and the distributions of the mental health scores of the sample for each wave and for the difference between waves. We then estimate a series of linear regression models to examine associations between mental health and (1) sociodemographic characteristics and (2) making three types of important transitions - in education, employment, and marriage - with changes in mental health over time.

Linear regression analyses of the correlates of the mental health summary index include the following sociodemographic characteristics: age group (in 2009: 13-19, 20- 
24, and 25-29), marital status (married or single), religion (Muslim or Christian), highest level of schooling attended (none, primary, preparatory, academic secondary, vocational secondary, or above secondary), current school enrollment status, employment status (employed, unemployed, or out of the labor force), household wealth quintile, and a variable capturing the major geographic zones of Egypt: the urban governorates (Cairo, Alexandria, Suez, and Port Said), urban Lower Egypt, rural Lower Egypt, urban Upper Egypt, rural Upper Egypt, and the frontier governorates. Regressions for the mental health score in each survey wave are predicted by the sociodemographic characteristics measured in the same wave.

We further exploit the panel dimension of the SYPE and examine the associations between transitions in education, employment, and marriage with changes in respondents' mental health score over time. For each individual, responses to the same questions for 2014 can be compared to those for 2009 to examine any changes over time. We transform the panel data by first-differencing all variables, expressing both independent and dependent variables as the change in levels between 2009 and 2014; any variables that do not vary over time thus drop out of the equation. The firstdifferenced transformation isolates the within-individual variation and essentially controls for other unobservable time-invariant factors related to mental health that may vary across individuals. In other words, unobservable stable factors that may affect both mental health status and the likelihood of making a transition for a given person (e.g., personality) are accounted for. We can additionally add controls for observable sociodemographic characteristics measured at baseline (i.e., in 2009) to further control for any initial differences in observable characteristics between individuals. Our regression model is specified as follows:

$$
\Delta Y_{i t}=\beta_{0}+\beta_{1} \Delta X_{i t}+\beta_{2} I_{i 2009}+e_{i t}
$$

where $\Delta Y_{i t}=Y_{i, t+1}-Y_{i, t}$ for mental health score $Y$ for individual $i$ in year $t, \Delta X_{i t}=$ $X_{i, t+1}-X_{i, t}$ for time-varying individual characteristics, and $I_{i 2009}$ represents baseline individual characteristics.

We chose to conduct our analyses using a linear Ordinary Least Squares (OLS) regression model for two reasons. First, our main outcome variable of interest, the SRQ-20 mental health summary index, is a continuous variable that reflects the simple addition of SRQ-20 component items, and does not have a discrete or ordinal interpretation (see Figure 1 for the cumulative probability distribution of each index measure by survey wave and gender). Second, when the summary index is firstdifferenced, the result is again a continuous variable that can now take on both positive and negative values (ranging from -20 to +20 ), has a distribution that is approximately 
normal, and satisfies the basic assumptions necessary for the OLS estimator (see Figure 2 for the distributions of the first-differenced measures by gender and age group).

Figure 2: Differences in the mental health summary index (2014-2009) by sex and age

A. Men

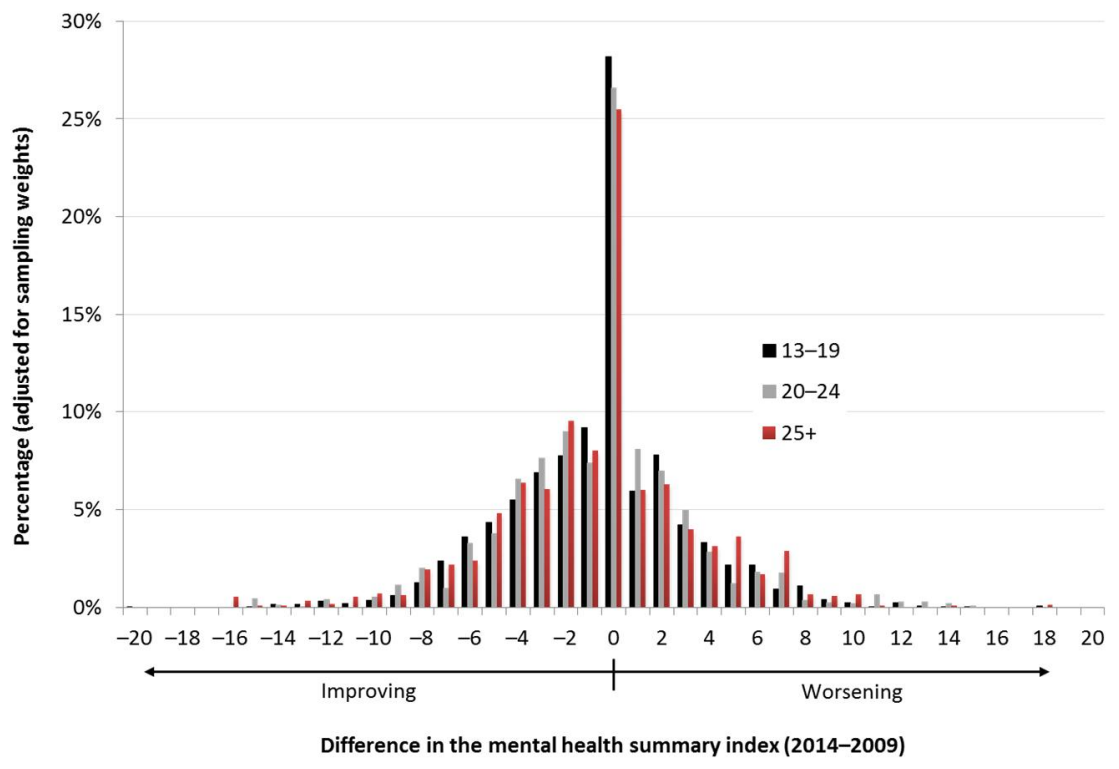




\section{Figure 2: (Continued)}

\section{B. Women}

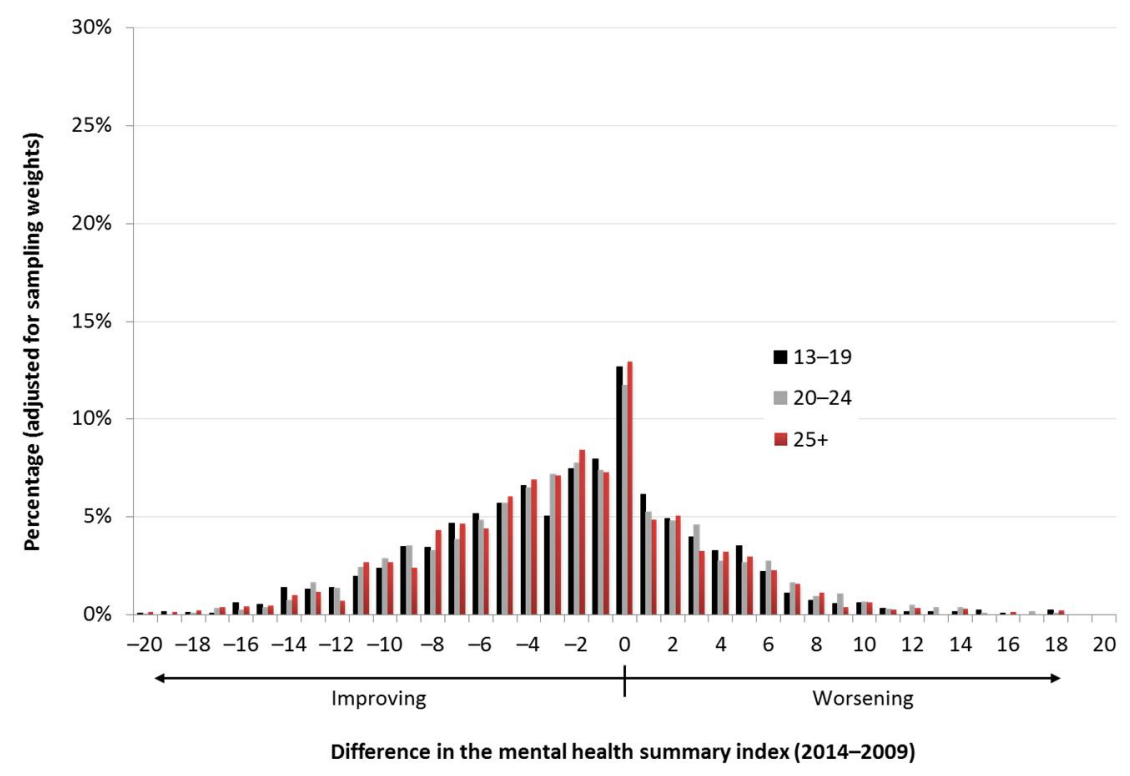

Notes: When the change in the mental health index is specified as the difference between the 2014 and 2009 scores (i.e., firstdifferenced), the probability density distribution shows that a large percentage of men (43.4\%) and an even larger percentage of women $(59.8 \%)$ have mental health scores that increase. In absolute terms, these increases are larger for women than for men. A similar percentage of men and women show worsening mental health $-29.5 \%$ and $27.8 \%$, respectively. Although not statistically different, disaggregating the density distribution by age shows that a slightly higher percentage of men in the oldest age category (25-29 in 2009; 30-35 in 2014) appear in the higher range of worsening scores. Density distributions for different age groups of women show few systematic substantive differences.

Given the sociocultural context in Egypt and the prevalence of different types of transitions, we defined the changes in each life domain as dummy variables constructed as follows:

\section{1) Education}

- 'Finished school' represents any individual who was enrolled in school in 2009 but was not enrolled in 2014. A person may have left school for any reason. In our sample, this was most often due to completing the desired level (e.g., completed secondary school) but also includes a minority of individuals who dropped out of school and did not intend to return. 
- 'Reentered school' represents any individual who was not enrolled in school in 2009 but was then enrolled in 2014. These individuals may have previously dropped out of school before achieving a terminal degree and wished to return to complete the degree, or having completed a terminal degree decided that they would like to return to school for a higher degree.

\section{2) Employment}

- 'Became employed' represents any individual who was either unemployed or not in the labor force (e.g., in school) in 2009 and was subsequently employed in 2014.

- 'Became unemployed or left the labor force' represents any individual who was employed in 2009 but lost or left their job by 2014 .

- 'Entered the labor force, but became unemployed' represents an individual who was not in the labor force in 2009 (e.g., due to schooling), and subsequently entered the labor force to search for a job but was not able to find one by 2014 .

\section{3) Marriage}

- 'Newly married' represents any individual who was single in 2009 but married in 2014. No instances of divorce or becoming widowed were observed between the two waves.

Because the SYPE sample covers a wide age range of young people at different stages of the transition to adulthood, we further conduct our analyses of transitions and mental health changes separately for three age groups: those aged 13-19, 20-24, and 25-29 in 2009. This disaggregation follows life course theory in drawing attention to the likelihood of age grading in both young people's psychosocial development and expectations around their transitions. For example, marriage may become increasingly normative for older individuals and therefore remaining single may become more stressful for young adults who may feel that they are falling behind their peers. Similarly, completing secondary schooling and entering the labor force is likely more important for the youngest youth in 2014 compared to older individuals who have been in the labor force for many years.

All regression models are run separately by gender and are adjusted for sampling weights. Standard errors are corrected for heteroskedasticity and are clustered at the primary sampling unit to account for potential spatial autocorrelation. 


\section{Results}

\subsection{Sample characteristics}

Table 2 displays the sociodemographic characteristics for our SYPE mental health panel as measured at baseline in 2009. The sample of young women is somewhat older and less educated. Large differences exist for marriage and employment: $44.6 \%$ of women were married and $87.3 \%$ were not in the labor force. In contrast, only $14.7 \%$ of men were married and 52.8\% were employed. Table 2 also shows the prevalence of different transitions occurring between 2009 and 2014. The percentage of young men finishing school was slightly higher than among young women, but school reentry rates were similar across genders albeit low overall (3.8\% and 4.4\%, respectively). Gender differences in employment transitions were more pronounced: $26.0 \%$ of young men had become employed since 2009 compared to only $9.0 \%$ of young women. A small percentage of both groups became unemployed or left the labor force $(6.9 \%$ and $8.9 \%$, respectively) or entered the labor force, but failed to find a job $(3.4 \%$ and $4.6 \%$, respectively). Similar percentages of young men and women also got married (19.0\% and $19.5 \%$, respectively).

\section{Table 2: $\quad$ Panel survey sample characteristics}

\begin{tabular}{lcc}
\hline & $\begin{array}{l}\text { Men } \\
\mathrm{N}=3,316\end{array}$ & $\begin{array}{c}\text { Women } \\
\mathrm{N}=4,065\end{array}$ \\
2009 baseline levels & & \\
\hline Age group & $45.3 \%$ & $40.2 \%$ \\
$13-19$ & $32.8 \%$ & $33.4 \%$ \\
$20-24$ & $21.9 \%$ & $26.4 \%$ \\
$25+$ & & \\
Education & $3.1 \%$ & $13.0 \%$ \\
$\quad$ Never attended & $15.5 \%$ & $14.8 \%$ \\
$\quad$ Primary & $25.2 \%$ & $23.0 \%$ \\
$\quad$ Preparatory & $11.4 \%$ & $9.4 \%$ \\
$\quad$ Secondary & $32.8 \%$ & $28.7 \%$ \\
$\quad$ Vocational secondary & $12.1 \%$ & $11.1 \%$ \\
$\quad$ Beyond secondary & & \\
School enrollment & $67.7 \%$ & $72.8 \%$ \\
$\quad$ Out of school & $32.3 \%$ & $27.2 \%$ \\
$\quad$ Currently in school & & \\
Marital status & $85.3 \%$ & $55.4 \%$ \\
$\quad$ Not married & $14.7 \%$ & $44.6 \%$ \\
$\quad$ Married & & \\
Employment status & $52.8 \%$ & $8.7 \%$ \\
$\quad$ Employed & $8.1 \%$ & $4.0 \%$ \\
$\quad$ Unemployed & $39.1 \%$ & $87.3 \%$ \\
$\quad$ Out of the labor force & & \\
Religion & & \\
$\quad$ Muslim & $96.4 \%$ & $96.4 \%$ \\
$\quad$ Christian & $3.6 \%$ & $3.6 \%$ \\
\hline
\end{tabular}


Table 2: (Continued)

\begin{tabular}{lcc}
\hline & Men & Women \\
2009 baseline levels & $\mathrm{N}=3,316$ & $\mathrm{~N}=4,065$ \\
\hline Wealth & & \\
$\quad$ Poorest & $20.0 \%$ & $21.7 \%$ \\
Second & $21.4 \%$ & $20.4 \%$ \\
Middle & $23.3 \%$ & $21.5 \%$ \\
Fourth & $19.8 \%$ & $19.5 \%$ \\
$\quad$ Richest & $15.5 \%$ & $16.9 \%$ \\
Region & & \\
Urban Governorates & $19.7 \%$ & $18.6 \%$ \\
Urban Lower Egypt & $11.2 \%$ & $12.3 \%$ \\
Rural Lower Egypt & $32.5 \%$ & $30.6 \%$ \\
Urban Upper Egypt & $8.8 \%$ & $8.0 \%$ \\
Rural Upper Egypt & $26.8 \%$ & $29.6 \%$ \\
Frontier Governorates & $1.1 \%$ & $1.0 \%$ \\
& & \\
Transitions between 2009 and 2014 & & \\
\hline Changes in schooling & & \\
None & $71.7 \%$ & $76.3 \%$ \\
Finished school & $23.9 \%$ & $19.9 \%$ \\
$\quad$ Reentered school & $4.4 \%$ & $3.8 \%$ \\
Changes in employment & & \\
None & $61.7 \%$ & $79.4 \%$ \\
Became employed & $26.0 \%$ & $9.0 \%$ \\
Became unemployed or left the labor force & $8.9 \%$ & $6.9 \%$ \\
Entered labor force but became unemployed & $3.4 \%$ & $4.6 \%$ \\
Marriage & & \\
$\quad$ No change & $80.5 \%$ & $19.0 \%$ \\
$\quad$ Newly married & $19.5 \%$ & \\
\hline
\end{tabular}

\subsection{Mental health status}

Individual responses to the SRQ-20 index items are shown in Table 1. Certain component items are more prevalent for both young men and women, including having headaches, poor appetite, poor sleep, feeling nervous, trouble thinking clearly, feeling unhappy, and having difficulty making decisions. In general, the prevalence of positive responses to each item is higher among young women than among young men, resulting in a mean summary score of 2.29 and 4.90 for young men and women, respectively, in 2009. Hence, the cumulative probability distribution (Figure 1) for young men in both SYPE waves lies everywhere to the left of the distribution for young women, indicating that young women have categorically worse mental health (i.e., a higher mental health score). For example, in 2009 94\% of young men have a mental health score less than 8 , the threshold indicated for poor mental health, compared to only $74 \%$ of young women who score less than 8 . In other words, in $2009,6 \%$ and $26 \%$ of young men and women, respectively, have poor mental health. In addition, the 
distribution for men is also more concentrated, with a smaller variance as compared to a more dispersed distribution for women.

The cumulative probability distribution of the mental health summary index across waves also shows that mental health improves over time for all individuals on average. The percentage of positive responses for individual SRQ-20 items declines or remains the same for all items. The overall improvement in the summary index for women is relatively larger than it is for men, closing the gender gap, but women still show relatively worse mental health in 2014. The average index score reduces to 1.68 for men and 2.73 for women. Thus, in 2014 , only $3.8 \%$ and $11.0 \%$ of young men and women, respectively, could be considered to have an index score that exceeds the poor mental health threshold.

When the change in the mental health index is specified as the difference between the 2014 and 2009 scores (i.e., first-differenced), the probability density distribution (Figure 2) shows that a large percentage of men (43.4\%) and an even larger percentage of women $(59.8 \%)$ have mental health scores that improve. In absolute terms, these improvements are larger for women than for men. A similar percentage of men and women show worsening mental health $-29.5 \%$ and $27.8 \%$, respectively - with more scores for women reaching higher positive differences. Although not statistically different, disaggregating the density distribution by age shows that a slightly higher percentage of men in the oldest age category (25-29 in 2009; 30-35 in 2014) appear in the higher range of worsening scores. Density distributions for different ages groups of women show few systematic substantive differences.

\subsection{Sociodemographic predictors of mental health status}

Table 3 displays the results of linear regressions predicting the mental health summary index score with sociodemographic characteristics for each survey wave. Results for young women are more consistent across waves than those for young men. For men, increasing educational attainment, in comparison to having never gone to school, and being currently in school is significantly associated with better mental health in 2009 . Being out of the labor force is significantly associated with worse mental health for men; this group includes both current students and nonstudents. However, in 2014, schooling is no longer a factor. Rather, being married is associated with better mental health. Being older and unemployed also emerge as a marginally significant risk factors for worse mental health. For women, schooling beyond secondary school is consistently associated with better mental health. However, enrollment status shows opposing directionality between waves: in 2009, being enrolled in school is associated with better mental health but becomes a risk factor for worse mental health in 2014. In 2014, being 
Liu, Modrek \& Sieverding: The mental health of young adults during the transition to adulthood in Egypt

out of the labor force is associated with significantly better mental health, but those aged 25-29 at the time (age 20-24 in 2009) have worse mental health (the result is marginally significant).

Table 3: Linear regression analysis of sociodemographic correlates of the mental health summary index by survey year

\begin{tabular}{|c|c|c|c|c|}
\hline & \multicolumn{2}{|c|}{ Men } & \multicolumn{2}{|c|}{ Women } \\
\hline & 2009 & 2014 & 2009 & 2014 \\
\hline & $(1)$ & $(2)$ & (3) & $(4)$ \\
\hline \multirow[t]{2}{*}{ Age 20-24 (in 2009) } & 0.17 & 0.21 & -0.14 & $0.29^{*}$ \\
\hline & $(0.19)$ & $(0.15)$ & $(0.23)$ & $(0.15)$ \\
\hline \multirow[t]{2}{*}{ Age $25+$ (in 2009) } & 0.38 & $0.39^{*}$ & 0.066 & 0.19 \\
\hline & $(0.25)$ & $(0.20)$ & $(0.26)$ & $(0.18)$ \\
\hline \multirow[t]{2}{*}{ Married } & -0.19 & $-0.32^{* *}$ & -0.20 & -0.018 \\
\hline & $(0.20)$ & $(0.16)$ & $(0.22)$ & $(0.19)$ \\
\hline \multirow[t]{2}{*}{ Muslim } & -0.55 & -0.37 & 0.21 & 0.14 \\
\hline & $(0.37)$ & $(0.51)$ & $(0.57)$ & $(0.55)$ \\
\hline \multirow[t]{2}{*}{ Primary school } & $-1.21^{\star \star *}$ & 0.15 & 0.038 & 0.16 \\
\hline & $(0.44)$ & $(0.41)$ & $(0.36)$ & $(0.35)$ \\
\hline \multirow[t]{2}{*}{ Preparatory school } & $-1.07^{\star \star}$ & -0.12 & -0.27 & 0.11 \\
\hline & $(0.43)$ & $(0.40)$ & $(0.35)$ & $(0.32)$ \\
\hline \multirow[t]{2}{*}{ Secondary school } & $-1.08^{\star *}$ & 0.12 & -0.050 & 0.051 \\
\hline & $(0.47)$ & $(0.49)$ & $(0.42)$ & $(0.42)$ \\
\hline \multirow[t]{2}{*}{ Vocational secondary school } & $-1.45^{\star \star \star}$ & -0.17 & -0.49 & $-0.51^{*}$ \\
\hline & $(0.46)$ & $(0.38)$ & $(0.30)$ & $(0.27)$ \\
\hline \multirow[t]{2}{*}{ Beyond secondary school } & $-1.99^{\star * *}$ & -0.52 & $-0.83^{* *}$ & $-0.97^{\star * *}$ \\
\hline & $(0.44)$ & $(0.39)$ & $(0.40)$ & $(0.32)$ \\
\hline \multirow[t]{2}{*}{ Currently in school } & $-1.02^{\star \star \star}$ & -0.18 & $-0.80^{\star \star}$ & $0.81^{\star \star \star *}$ \\
\hline & $(0.29)$ & $(0.18)$ & $(0.32)$ & $(0.30)$ \\
\hline \multirow[t]{2}{*}{ Unemployed } & $0.41^{*}$ & $0.41^{*}$ & -0.21 & 0.21 \\
\hline & $(0.23)$ & $(0.25)$ & $(0.48)$ & $(0.45)$ \\
\hline \multirow[t]{2}{*}{ Out of the labor force } & $0.70^{\star \star \star}$ & 0.069 & -0.18 & $-0.49^{* *}$ \\
\hline & $(0.26)$ & $(0.16)$ & $(0.33)$ & $(0.23)$ \\
\hline \multirow[t]{2}{*}{ Second wealth quintile } & -0.27 & -0.092 & -0.28 & 0.23 \\
\hline & $(0.20)$ & $(0.20)$ & $(0.24)$ & $(0.23)$ \\
\hline \multirow[t]{2}{*}{ Middle wealth quintile } & -0.19 & -0.23 & -0.41 & -0.10 \\
\hline & $(0.21)$ & $(0.21)$ & $(0.27)$ & $(0.23)$ \\
\hline \multirow[t]{2}{*}{ Fourth wealth quintile } & -0.083 & -0.25 & $-0.68^{* *}$ & -0.22 \\
\hline & $(0.23)$ & $(0.21)$ & $(0.32)$ & $(0.23)$ \\
\hline \multirow[t]{2}{*}{ Richest wealth quintile } & -0.37 & $-0.39^{*}$ & $-1.07^{\star * *}$ & -0.31 \\
\hline & $(0.26)$ & $(0.21)$ & $(0.39)$ & $(0.27)$ \\
\hline \multirow[t]{2}{*}{ Urban Lower Egypt } & 0.30 & $-0.62^{\star \star}$ & $-0.86^{\star *}$ & $-1.55^{\star \star *}$ \\
\hline & $(0.30)$ & $(0.27)$ & $(0.36)$ & $(0.36)$ \\
\hline \multirow[t]{2}{*}{ Rural Lower Egypt } & 0.32 & $-0.72^{\star \star *}$ & $-1.57^{\star * *}$ & $-1.42^{\star \star *}$ \\
\hline & $(0.23)$ & $(0.22)$ & $(0.32)$ & $(0.34)$ \\
\hline \multirow[t]{2}{*}{ Urban Upper Egypt } & 0.45 & $-0.76^{\star \star}$ & $-0.88^{*}$ & $-1.46^{\star \star \star}$ \\
\hline & $(0.34)$ & $(0.32)$ & $(0.50)$ & $(0.40)$ \\
\hline \multirow[t]{2}{*}{ Rural Upper Egypt } & 0.036 & -0.21 & $-1.62^{\star \star \star}$ & $-0.92^{\star *}$ \\
\hline & $(0.26)$ & $(0.26)$ & $(0.38)$ & $(0.41)$ \\
\hline
\end{tabular}


Table 3: (Continued)

\begin{tabular}{|c|c|c|c|c|}
\hline & \multicolumn{2}{|c|}{ Men } & \multicolumn{2}{|c|}{ Women } \\
\hline & $\begin{array}{l}2009 \\
(1)\end{array}$ & $\begin{array}{l}2014 \\
(2)\end{array}$ & $\begin{array}{l}2009 \\
(3)\end{array}$ & $\begin{array}{c}2014 \\
(4)\end{array}$ \\
\hline Frontier Governorates & $\begin{array}{c}0.58 \\
(0.44)\end{array}$ & $\begin{array}{c}-0.69^{*} \\
(0.41)\end{array}$ & $\begin{array}{l}-0.57 \\
(0.53)\end{array}$ & $\begin{array}{l}-2.19^{\star \star \star} \\
(0.44)\end{array}$ \\
\hline Constant & $\begin{array}{l}4.01^{* * *} \\
(0.58)\end{array}$ & $\begin{array}{l}2.83^{\star \star \star} \\
(0.64)\end{array}$ & $\begin{array}{l}7.09^{\star \star \star} \\
(0.81)\end{array}$ & $\begin{array}{l}4.34^{\star * \star} \\
(0.82)\end{array}$ \\
\hline Observations & 3,316 & 3,316 & 4,065 & 4,065 \\
\hline R-squared & 0.033 & 0.032 & 0.022 & 0.042 \\
\hline
\end{tabular}

Notes: ${ }^{* *} p<0.01,{ }^{* *} p<0.05,{ }^{*} p<0.1$. Robust and clustered standard errors in parentheses.

\subsection{Associations of key life transitions with changes in mental health}

Table 4 summarizes the estimates of education, employment, and marriage transitions on changes in the mental health index in first-differenced multivariate regressions. For young men, getting married was significantly associated with improvement in mental health (a decrease in the difference of the mental health scores). Across age groups, we find that the protective effect of marriage was driven by the large and significant effect among the oldest cohorts. While transitions in education did not have an overall effect among young men, there was a significant improvement in mental health for those in the middle age group related to finishing school. For employment, mental health significantly worsened among the oldest men who entered the labor force but were not able to find a job.

For young women, transitions in education and employment appear to affect mental health. Finishing school was significantly related to an improvement in mental health for all ages. However, when disaggregated by age, diverging effects are observed for oldest cohort, in which finishing school was associated with a large and significant worsening in mental health. In contrast, women in the middle age group experienced a large and significant improvement in mental health. Entering the labor force and failing to find a job significantly worsened mental health for all ages, primarily driven by effects observed for the youngest cohort. Becoming married did not have a measurable effect on changes in mental health. 
Liu, Modrek \& Sieverding: The mental health of young adults during the transition to adulthood in Egypt

Table 4: Analysis of education, employment, and marriage transitions and changes in the mental health summary index (2014-2009)

\begin{tabular}{|c|c|c|c|c|c|c|c|c|}
\hline & \multicolumn{4}{|c|}{ Men } & \multicolumn{4}{|c|}{ Women } \\
\hline & $\begin{array}{c}\text { All ages } \\
(1)\end{array}$ & $\begin{array}{c}13-19 \\
(2)\end{array}$ & $\begin{array}{c}20-24 \\
(3)\end{array}$ & $\begin{array}{l}25+ \\
(4)\end{array}$ & $\begin{array}{c}\text { All ages } \\
(5)\end{array}$ & $\begin{array}{c}13-19 \\
(6)\end{array}$ & $\begin{array}{c}20-24 \\
(7)\end{array}$ & $\begin{array}{c}25+ \\
(8) \\
\end{array}$ \\
\hline \multicolumn{9}{|l|}{ Education } \\
\hline Finished school & $\begin{array}{l}-0.31 \\
(0.28)\end{array}$ & $\begin{array}{r}-0.044 \\
(0.29)\end{array}$ & $\begin{array}{c}-2.24^{\star \star \star} \\
(0.86)\end{array}$ & $\begin{array}{c}1.27 \\
(2.09)\end{array}$ & $\begin{array}{c}-1.54^{\star \star *} \\
(0.47)\end{array}$ & $\begin{array}{c}-1.37^{\star \star \star} \\
(0.48)\end{array}$ & $\begin{array}{c}-6.86^{\star \star *} \\
(1.77)\end{array}$ & $\begin{array}{c}13.7^{* * * 1} \\
(1.76)\end{array}$ \\
\hline Entered school & $\begin{array}{c}0.45 \\
(0.47)\end{array}$ & $\begin{array}{r}-0.58 \\
(0.82)\end{array}$ & $\begin{array}{c}0.99 \\
(0.70)\end{array}$ & $\begin{array}{c}0.94 \\
(0.70)\end{array}$ & $\begin{array}{c}0.56 \\
(0.52)\end{array}$ & $\begin{array}{c}0.14 \\
(1.03)\end{array}$ & $\begin{array}{l}1.79^{\star \star} \\
(0.86)\end{array}$ & $\begin{array}{r}-0.58 \\
(0.75)\end{array}$ \\
\hline \multicolumn{9}{|l|}{ Employment } \\
\hline Became employed & $\begin{array}{l}-0.11 \\
(0.28)\end{array}$ & $\begin{array}{l}-0.13 \\
(0.30)\end{array}$ & $\begin{array}{c}0.20 \\
(0.60)\end{array}$ & $\begin{array}{c}0.32 \\
(1.51)\end{array}$ & $\begin{array}{c}0.27 \\
(0.39)\end{array}$ & $\begin{array}{c}0.30 \\
(0.58)\end{array}$ & $\begin{array}{l}-0.15 \\
(0.59)\end{array}$ & $\begin{array}{l}0.90 \\
(0.78)\end{array}$ \\
\hline $\begin{array}{l}\text { Became unemployed or left the } \\
\text { labor force }\end{array}$ & $\begin{array}{l}-0.32 \\
(0.32)\end{array}$ & $\begin{array}{l}-0.47 \\
(0.45)\end{array}$ & $\begin{array}{c}0.41 \\
(0.57)\end{array}$ & $\begin{array}{l}-0.15 \\
(0.73)\end{array}$ & $\begin{array}{c}-0.0091 \\
(0.59)\end{array}$ & $\begin{array}{r}-1.59 \\
(1.56)\end{array}$ & $\begin{array}{r}-0.78 \\
(0.87)\end{array}$ & $\begin{array}{l}0.55 \\
(1.05)\end{array}$ \\
\hline $\begin{array}{l}\text { Entered the labor force, but } \\
\text { became unemployed }\end{array}$ & $\begin{array}{c}0.36 \\
(0.56)\end{array}$ & $\begin{array}{c}-0.0067 \\
(0.57)\end{array}$ & $\begin{array}{c}0.23 \\
(1.31)\end{array}$ & $\begin{array}{l}6.74^{\star \star *} \\
(2.18)\end{array}$ & $\begin{array}{l}1.29^{* *} \\
(0.65)\end{array}$ & $\begin{array}{l}2.32^{*} \\
(1.18)\end{array}$ & $\begin{array}{c}0.49 \\
(0.74)\end{array}$ & $\begin{array}{l}0.89 \\
(0.90)\end{array}$ \\
\hline \multicolumn{9}{|l|}{ Marriage } \\
\hline Newly married & $\begin{array}{c}-0.53^{\star \star} \\
(0.25)\end{array}$ & $\begin{array}{r}-0.047 \\
(0.44)\end{array}$ & $\begin{array}{l}-0.35 \\
(0.30)\end{array}$ & $\begin{array}{c}-1.23^{* *} \\
(0.53)\end{array}$ & $\begin{array}{c}0.16 \\
(0.32)\end{array}$ & $\begin{array}{c}0.28 \\
(0.38)\end{array}$ & $\begin{array}{c}0.32 \\
(0.54)\end{array}$ & $\begin{array}{c}-0.64 \\
(0.84)\end{array}$ \\
\hline Observations & 3,316 & 1,502 & 1,058 & 756 & 4,065 & 1,516 & 1,402 & 1,147 \\
\hline R-squared & 0.026 & 0.025 & 0.057 & 0.107 & 0.014 & 0.032 & 0.033 & 0.033 \\
\hline
\end{tabular}

Notes: ${ }^{1}$ Less than $1 \%$ of women in this group finished school. All regressions include controls for age, education, marital status, employment status, religion, wealth, and region at 2009 baseline levels. The outcome is the difference in the mental health summary index score between survey years (2014-2009). ${ }^{\star \star \star} p<0.01,{ }^{\star \star} p<0.05,{ }^{*} p<0.1$. Robust and clustered standard errors in parentheses.

\section{Discussion}

\subsection{Main findings}

The burden of poor mental health (Charara et al. 2017; Gater and Saeed 2015; Mokdad et al. 2014) and young people's stalled transitions to adulthood (Assaad and RoudiFahimi 2007; Dhillon and Yousef 2009) have both been identified as major policy challenges in MENA. However, to the best of our knowledge this is the first study to 
examine the relationship between these two issues within the region's large population of young people. Based on data from Egypt, our findings suggest that the ways in which different aspects of the transition to adulthood are associated with mental health depend on age and gender.

Our findings contribute to a growing literature that demonstrates a substantial burden of poor mental health in the MENA region (Charara et al. 2017; Mokdad et al. 2014, 2016). In particular, our analysis from a nationally representative panel survey concurs with previous literature that finds a substantial burden of poor mental health among young people (Ferrari et al. 2013; Ghanem et al. 2009; Mokdad et al. 2014; Whiteford et al. 2013). We also find that the burden of poor mental health is particularly high among young women, as is found at a global level (Ferrari et al. 2013; Murray et al. 2012), in the MENA region (Charara et al. 2017; Mokdad et al. 2014; World Health Organization 2011), and within the Egyptian population (Ghanem et al. 2009). Globally, researchers largely explain gender differences in the burden of poor mental health in terms of social and institutional factors that place women at greater risk of being socioeconomically disempowered relative to men. These factors include having access to fewer resources and being at greater risk for abuse (World Health Organization 2000). In the MENA region, studies also note that the tension between socioeconomic changes, including rapidly rising educational attainments and expanding economic opportunities for women outside the home, and traditional social norms toward gender roles and hierarchical structures within the home, may contribute to increased anxiety and stress for women (Douki et al. 2007; El-Islam 2001).

These social and institutional factors that place women at greater risk for poor mental health may be especially pronounced among younger cohorts that are transitioning to adulthood. Young women in the SYPE reported more adverse symptoms related to mental health compared to young men, and more young women were categorized as having mental illness in both years. This confirms findings from a study of adolescents (aged 15-19) in the Arab region that finds a higher burden of mental disorders compared to global averages and an especially high burden among adolescent girls (Obermeyer, Bott, and Sassine 2015). The authors speculate that unequal gender norms contribute to the disproportionately high burden of poor mental health among adolescent girls; this may be true among the population of older youth and young adults included in our study as well.

Even though mental health scores were systematically worse for young women in both waves of the SYPE, scores also improved, on average, for both genders over time. Yet, researchers caution that overall trends can mask important differences in trajectories of well-being during the transition to adulthood that are context-dependent and which result in diverging mental health outcomes (Gutman and Sameroff 2004; Masten et al. 2004; Schulenberg, Sameroff, and Cicchetti 2004). As has been 
empirically observed at the population level, greater autonomy in decision-making with age can increase overall well-being for many individuals as they gain more responsibility and self-determination (Schulenberg et al. 2005). However, lack of structure and discordance between individual desires and what is achievable can adversely affect mental health for others (Mortimer et al. 2002). In selected samples, young women have been found to experience more depression than young men, even though depression increased in both sexes during the transition from high school to college (Alfeld-Liro and Sigelman 1998). In our analysis of the SYPE data we also see that even though mental health improves overall with age for the vast majority of individuals, over a quarter of the sample experienced worsening mental health between 2009 and 2014, demonstrating substantial variation in mental health trajectories over time. The SRQ-20 mental health summary index also appears to be more sensitive for women than men, in that the distribution among women shows greater variation in each survey year and over time. These variations in mental health trajectories during the life course enable us to empirically test the association of mental health with the attainment (or lack thereof) of key developmental milestones in the transition to adulthood.

The three key transitions among young people entering adulthood in MENA are finishing school, entering the labor force, and getting married (Dhillon, Yousef, and Dyer 2009). Beginning with education, we find that higher educational attainment is associated with better mental health for both young men and women. Whereas each additional level of education is protective for young men, education is only protective beyond secondary schooling for women, results that are consistent with another study in Egypt that finds both secondary and tertiary education to be protective for men, but only tertiary education to be protective for women in terms of mental health status (Ghanem et al. 2009). As tertiary education is also associated with strong labor market (Assaad and El Hamidi 2009) and marriage market (Elbadawy 2009) benefits for women, this result suggests an important role for higher education in women's broader well-being in Egypt. Finishing school is also associated with improved mental health for men in the middle age group, who are completing some vocational secondary tracks and university degrees on time with their cohorts. For women, finishing school is similarly protective for those under age 24 , and particularly those in the same age group (20-24 years old) where benefits are seen for men. This may be related to the fact that education is more widely held to be an important achievement in and of itself for young women in Egypt, and is not necessarily seen primarily as an investment towards paid employment (Elbadawy 2009; Sieverding and Hassan 2016). In contrast, for the oldest group of women (ages 25-29), finishing school is associated with worsening mental health. However, this is a very small group of women $(<1 \%)$ who were primarily finishing their education after marriage, which is uncommon in Egypt, so the result should be considered with caution. 
Upon completing their education, successful transition to work is an important step towards full adulthood for young men in MENA (Assaad, Binzel, and Gadallah 2010; Dhillon and Yousef 2009; Salem 2016). In contrast, a large percentage of Egyptian women never work (Assaad and El Hamidi 2009; Roushdy and Selwaness 2015), so entering paid employment is not an expected step in young women's transition to adulthood. Many women who do work view this as a temporary activity during the period between finishing school and getting married (Amin and Al-Bassusi 2004; Barsoum 2004), but employment nevertheless has no impact on women's likelihood of marrying (Salem 2016). Our results reflect some of these varied expectations for young people's labor market participation by gender. Being out of the labor force is a mental health risk factor among men, but is protective for women, particularly in 2014 when the sample is older. Similarly, being unemployed is a marginally significant risk factor for men. Entering the labor force but remaining unemployed - which corresponds to the challenge of failed youth insertion into the labor market that is noted in the literature (Assaad 2008) - is also associated with poorer mental health for the oldest group of young men (ages 25-29), who are likely facing the greatest pressure to obtain good jobs in preparation for marriage and independent family formation. This transition, or rather failed transition to work, is also a risk factor for young women, which may correspond to the high unemployment rates and long unemployment durations among the highly selected group of young women who decide to look for work (Roushdy and Selwaness 2015).

Marriage is the marker of full adulthood status for both young men and women in Egypt (Salem 2016; Singerman 2007). Our results indicate that marriage is protective for young men, but is unrelated to changes in mental health for young women, and that entering marriage is associated with a significant improvement in young men's mental health, particularly for the oldest age group. Such association is not observed for women, which is somewhat surprising given the significance of marriage in women's lives. While this milestone may reflect a positive achievement, several contextual changes concurrent with marriage may negatively affect women's mental well-being. The vast majority of young Egyptians live with their parents until marriage, at which point residence is typically independent or patrilocal (Salem 2015). Young women moving into a household upon marriage may be distanced from the protective social resources of their natal family and need to adjust to a new home and social environment. Indeed, family and neighborhood ecological factors in adulthood have been found to be related to depression among young women outside of MENA (Gutman and Sameroff 2004). In Egypt, changes in these ecological factors may be brought about upon marriage. For example, married women spend substantial amounts of time in housework and childcare, and are generally expected to bear primary responsibility for these activities (Hendy 2015; Sieverding and Hassan 2016), 
engendering stresses that may be greater for young women adjusting to their new role. Unfortunately, as marriage corresponds closely to the timing of the first birth in Egypt, the SYPE data does not allow us to examine independent associations between mental health, entry into marriage, and entry into parenthood.

\subsection{Limitations}

There are several other limitations to our analysis. There was $27 \%$ attrition between the SYPE survey waves, although sampling weights are used in all summary statistics and regression analyses to adjust for representativeness. Further, even while we have examined the relationship between changes in mental health and changes in education, employment, and marital statuses over time via a first-differencing approach, we cannot conclude that our transition regression analyses show a causal relationship. There may be unobservable time-varying factors that affect both mental health and the likelihood of making an important life transition (e.g., shocks to the household) and the relationship between these changes may be interdependent. It should also be noted that the SRQ-20 is only one measure of mental health status and numerous other measures exist that may yield different insights into the distribution of mental health burden of disease and its relationship to life events. While each measure has a specific purpose in assessing different aspects of mental health (e.g., depression, anxiety, stress) and has advantages and disadvantages, we are limited to the measure that is available in the existing data. This is particularly true as we are unaware of other nationally representative surveys in Egypt that include both mental health measures and detailed sociodemographic variables.

Finally, additional research is needed to understand the specific challenges and facilitators that young people of different ages and genders face in these critical life stages, particularly in terms of events closely associated with marriage (e.g., new household formation, family formation and childbearing, and assumption of new adult roles) that cannot be disentangled here. Given the limitations of the SYPE data, especially with respect to a lack of data on timing of births, and our quantitative approach (which reduces complex processes to a single variable indicator), we are only able to assess the net effect of transitions in education, employment, and marriage. Other contextual changes that may be occurring at the same time cannot be analyzed separately using this approach. Complimentary qualitative approaches are needed to further examine the mechanisms by which completing or not completing these key transitions affect young people's mental health.

Despite these caveats, this is one of the first studies to use nationally representative data to examine the mental health of young people in Egypt, as well as the MENA 
region more broadly. The panel structure of SYPE also allows us to examine the association between the transition to adulthood and young people's mental health, which adds an important new dimension to the literature on the transition to adulthood in MENA, which has previously focused primarily on socioeconomic outcomes.

\section{Conclusion}

Existing literature on the mental health implications of young people's experiences during the transition to adulthood is focused heavily on high-income countries, where institutional contexts, opportunity structures, and age- and gender-based norms around social roles differ substantially from those in MENA or other less developed contexts. At the same time, the literature on the transition to adulthood in MENA has drawn heavily on the socioeconomic dimensions of life course theory, while neglecting the broader developmental origins of the approach and the potential linkages between socioeconomic and psychosocial outcomes. Our results suggest that this is a key gap in our understanding of the implications of stalled transitions to adulthood in the region, and potentially other regions experiencing a youth bulge. Whether achieving, or failing to achieve, key life transitions is protective or a risk factor for mental health outcomes appears to be related to gendered, and possibly age-related, expectations for young people's social roles. As these expectations vary considerably across contexts, e.g., in the area of women's employment, country-specific and comparative research on the transition to adulthood is all the more important.

Overall, our results suggest that reaching age- and gender-appropriate milestones leads to better mental health among young people. In a context where socioeconomic outcomes among youth and young adults are a major focus of academic and popular discussion, this indicates that further research examining the linkages between young people's health and their socioeconomic outcomes is key to understanding the full picture of their well-being in the region. This research should address other indicators of mental health among young people as well as risk behaviors and broader measures of well-being; doing so will require further investments in interdisciplinary survey data collection efforts that allow for the examination of linkages between health and socioeconomic outcomes. Longitudinal surveys such as the SYPE are particularly important to this research agenda given the political transitions and associated economic downturn currently being experienced in Egypt and elsewhere in the MENA region. Life course research from other contexts finds that there are period effects, sometimes induced by major upheavals such as wars, that may alter life course expectations for cohorts that are transitioning to adulthood at the time (Elder and Rockwell 1979; Hogan and Astone 1986; Shanahan 2000). While the limited research 
on youth outcomes and employment expectations that has been conducted in Egypt since the January 2011 Revolution suggest that these have not yet changed (Barsoum 2015; Roushdy and Sieverding 2015), it is possible that such changes will occur in the future.

Another area in which further research is needed in order to better understand the linkages between young people's socioeconomic and psychosocial outcomes over the transition to adulthood in MENA is related to aspirations. Research from other contexts suggests that aspirations, intentions, and the (perceived) ability to achieve them may have a profound effect on young people's behaviors and outcomes over the transition to adulthood (Shanahan 2000). Although frustrated aspirations among young people have become a topic of considerable concern in MENA, few studies - including our own have been able to concretely examine how the failure to achieve desired goals may impact young people's well-being. In order to fully understand the mechanisms between achievement of socioeconomic milestones and young people's psychosocial outcomes, this is a critical area for further investigation.

\section{Acknowledgments}

This research was funded by a grant from the National Institute on Child Health and Development (5R03 HD082532). The funders did not have any role in the study design, data collection, analysis, decision to publish, or preparation of the manuscript. 


\section{References}

Afifi, M. (2006). Depression in adolescents: Gender differences in Oman and Egypt. Eastern Mediterranean Health Journal 12(1-2): 61-71.

Alfeld-Liro, C. and Sigelman, C.K. (1998). Sex differences in self-concept and symptoms of depression during the transition to college. Journal of Youth and Adolescence 27(2): 219-244. doi:10.1023/A:1021667813858.

Amer, M. (2009). The Egyptian youth labor market school-to-work transition, 19882006. In: Assaad, R. (ed.). The Egyptian labor market revisited. Cairo: American University in Cairo Press: 117-156.

Amer, M. (2014). The school to work transition of Jordanian youth. In: Assaad, R. (ed.). The Jordanian labor market in the new millennium. Oxford: Oxford University Press: 64-104. doi:10.1093/acprof:oso/9780198702054.003.0003.

Amer, M. (2015). Patterns of labor market insertion in Egypt, 1998-2012. In: Assaad, R. and Krafft, C. (eds.). The Egyptian labor market in an era of revolution. Oxford: Oxford University Press: 70-89. doi:10.1093/acprof:oso/9780198737 254.003.0004.

Amin, S. and Al-Bassusi, N. (2004). Education, wage work, and marriage: Perspectives of Egyptian working women. Journal of Marriage and Family 66(5): 12871299. doi:10.1111/j.0022-2445.2004.00093.x.

Assaad, R. (1997). The effects of public sector hiring and compensation policies on the Egyptian labor market. The World Bank Economic Review 11(1): 85-118. doi:10.1093/wber/11.1.85.

Assaad, R. (2007). Institutions, household decisions, and economic growth in Egypt. In: Nugent, J. and Pesaran, M.H. (eds.). Explaining growth in the Middle East. Amsterdam: Elsevier: 385-411.

Assaad, R. (2008). Unemployment and youth insertion in the labor market in Egypt. In: Khayr al-Din, H. (ed.). The Egyptian economy: Current challenges and future prospects. Cairo: American University in Cairo: 133-178.

Assaad, R. and Barsoum, G. (2009). Rising expectations and diminishing opportunities for Egypt's young. In: Dhillon, N. and Yousef, T. (eds.). Generation in waiting: The unfulfilled promise of young people in the Middle East. Washington, D.C.: Brookings Institution: 67-94. 
Assaad, R., Binzel, C., and Gadallah, M. (2010). Transitions to employment and marriage among young men in Egypt. Middle East Development Journal 2(1): 39-88. doi:10.1142/S1793812010000162.

Assaad, R. and El Hamidi, F. (2009). Women in the Egyptian labor market: An analysis of developments, 1988-2006. In: Assaad, R. (ed.). The Egyptian labor market revisited. Cairo: American University in Cairo Press: 117-156. doi:10.5743/cairo/9789774162480.001.0001.

Assaad, R. and Levison, D. (2017). Facing the global challenge of youth employment. In: Besada, H., Polonenko, L.M., and Agarwal, M. (eds.). Did the MDGs work? Meeting future challenges with past lessons. Bristol: Policy Press.

Assaad, R. and Roudi-Fahimi, F. (2007). Youth in the Middle East and North Africa: Demographic opportunity or challenge. Washington, D.C: Population Reference Bureau.

Barsoum, G. (2004). The employment crisis of female graduates in Egypt: An ethnographic account. Cairo: American University in Cairo Press, Cairo Papers in Social Science.

Barsoum, G. (2015). Young people's job aspirations in Egypt and the continued preference for a government job. In: Assaad, R. and Krafft, C. (eds.). The Egyptian labor market in an era of revolution. Oxford: Oxford University Press: 108-126. doi:10.1093/acprof:oso/9780198737254.003.0006.

Beusenberg, M. and Orley, J.H. (1994). A user's guide to the Self Reporting Questionnaire (SRQ). Geneva: World Health Organization Division of Mental Health.

Bloom, D.E., Cafiero, E., Jané-Llopis, E., Abrahams-Gessel, S., Bloom, L.R., Fathima, S., Feigl, A.B., Gaziano, T., Hamandi, A., Mowafi, M., Pandya, A., Prettner, K., Rosenberg, L., Seligman, B., Stein, A.Z., and Weinstein, C. (2011). The global economic burden of noncommunicable diseases. Geneva: World Economic Forum.

Campante, F.R. and Chor, D. (2012). Why was the Arab world poised for revolution? Schooling, economic opportunities, and the Arab spring. The Journal of Economic Perspectives 26(2): 167-187. doi:10.1257/jep.26.2.167.

Charara, R., Forouzanfar, M., Naghavi, M., Moradi-Lakeh, M., Afshin, A., Vos, T., Daoud, F., Wang, H., Bcheraoui, C.E., Khalil, I., Hamadeh, R.R., Khosravi, A., Rahimi-Movaghar, V., Khader, Y., Al-Hamad, N., Obermeyer, C.M., Rafay, A., Asghar, R., Rana, S.M., Shaheen, A., Abu-Rmeileh, N.M.E., Husseini, A., Abu- 
Raddad, L.J., Khoja, T., Rayess, Z.A.A., AlBuhairan, F.S., Hsairi, M., Alomari, M.A., Ali, R., Roshandel, G., Terkawi, A.S., Hamidi, S., Refaat, A.H., Westerman, R., Kiadaliri, A.A., Akanda, A.S., Ali, S.D., Bacha, U., Badawi, A., Bazargan-Hejazi, S., Faghmous, I.A.D., Fereshtehnejad, S.-M., Fischer, F., Jonas, J.B., Defo, B.K., Mehari, A., Omer, S.B., Pourmalek, F., Uthman, O.A., Mokdad, A.A., Maalouf, F.T., Abd-Allah, F., Akseer, N., Arya, D., Borschmann, R., Brazinova, A., Brugha, T.S., Catalá-López, F., Degenhardt, L., Ferrari, A., Haro, J.M., Horino, M., Hornberger, J.C., Huang, H., Kieling, C., Kim, D., Kim, Y., Knudsen, A.K., Mitchell, P.B., Patton, G., Sagar, R., Satpathy, M., Savuon, K., Seedat, S., Shiue, I., Skogen, J.C., Stein, D.J., Tabb, K.M., Whiteford, H.A., Yip, P., Yonemoto, N., Murray, C.J.L., and Mokdad, A.H. (2017). The burden of mental disorders in the Eastern Mediterranean region, 1990-2013. PLOS ONE 12(1): e0169575. doi:10.1371/journal.pone. 0169575.

Dhillon, N. and Yousef, T. (2009). Generation in waiting: The unfulfilled promise of young people in the Middle East. Washington, D.C.: Brookings Institution Press.

Dhillon, N., Yousef, T., and Dyer, P. (2009). Generation in waiting: An overview of school to work and family formation transitions. In: Dhillon, N. and Yousef, T. (eds.). Generation in waiting: The unfulfilled promise of young people in the Middle East. Washington, D.C.: Brookings Institution Press: 11-38.

Douki, S., Ben Zineb, S., Nacef, F., and Halbreich, U. (2007). Women's mental health in the Muslim world: Cultural, religious, and social issues. Journal of Affective Disorders 102(1-3): 177-189. doi:10.1016/j.jad.2006.09.027.

El Kady, H.M. and Ibrahim, H.K. (2013). Depression among a group of elders in Alexandria, Egypt. Eastern Mediterranean Health Journal 19(2): 167-174.

Elbadawy, A. (2009). Three essays on education in Egypt [PhD thesis]. Hamilton: McMaster University, Department of Economics.

Elbadawy, A. (2015). Education in Egypt: Improvements in attainment, problems with quality and inequality. In: Assaad, R. and Krafft, C. (eds.). The Egyptian labor market in an era of revolution. Oxford: Oxford University Press: 127-146. doi:10.1093/acprof:oso/9780198737254.003.0007.

Elder, G.H. (1998). The life course as developmental theory. Child Development 69(1): 1-12. doi:10.2307/1132065. 
Elder, G.H. and Rockwell, R.C. (1979). The life-course and human development: An ecological perspective. International Journal of Behavioral Development 2(1): 1-21. doi:10.1177/016502547900200101.

El-Islam, M.F. (2001). Social psychiatry and the impact of religion. In: Okasha, A. and Maj, M. (eds.). Images in psychiatry: An Arab perspective. Cairo: WPA Publications: 21-35.

Ferrari, A.J., Charlson, F.J., Norman, R.E., Patten, S.B., Freedman, G., Murray, C.J.L., Vos, T., and Whiteford, H.A. (2013). Burden of depressive disorders by country, sex, age, and year: Findings from the Global Burden of Disease Study 2010. PLoS Med 10(11): e1001547. doi:10.1371/journal.pmed.1001547.

Gater, R. and Saeed, K. (2015). Scaling up action for mental health in the Eastern Mediterranean region: An overview. Eastern Mediterranean Health Journal 21(7): 535-550.

Ghanem, M., Gadallah, M., Meky, F.A., Mourad, S., and El Kholy, G. (2009). National survey of prevalence of mental disorders in Egypt: Preliminary survey. Eastern Mediterranean Health Journal 15(1): 65-75.

Ghubash, R., Daradkeh, T., El-Rufaie, O.F., and Abou-Saleh, M.T. (2001). A comparison of the validity of two psychiatric screening questionnaires: The Arabic General Health Questionnaire (AGHQ) and Self-Reporting Questionnaire (SRQ-20) in UAE, using Receiver Operating Characteristic (ROC) analysis. European Psychiatry 16(2): 122-126. doi:10.1016/S0924-9338(01)00549-1.

Goldstone, J.A. (2002). Population and security: How demographic change can lead to violent conflict. Journal of International Affairs 56(1): 3-21.

Gutman, L.M. and Sameroff, A.J. (2004). Continuities in depression from adolescence to young adulthood: Contrasting ecological influences. Development and Psychopathology 16(4): 967-984. doi:10.1017/S095457940404009X.

Hardie, J.H. (2014). The consequences of unrealized occupational goals in the transition to adulthood. Social Science Research 48: 196-211. doi:10.1016/j.ssresearch. 2014.06.006.

Hendy, R. (2015). Women's participation in the Egyptian labor market,1998-2012. In: Assaad, R. and Krafft, C. (eds.). The Egyptian labor market in an era of revolution. Oxford: Oxford University Press.

Hogan, D.P. and Astone, N.M. (1986). The transition to adulthood. Annual Review of Sociology 12: 109-130. doi:10.1146/annurev.soc.12.1.109. 
Kasemy, Z.A., Salama, A.A., Salem, M.E.A., and Negm, N. (2016). Factors related to depression symptoms among working women in Menoufia, Egypt. The Journal of the Egyptian Public Health Association 91(4): 163-168.

Lancet Global Mental Health Group (2007). Scale up services for mental disorders: A call for action. The Lancet 370(9594): 1241-1252. doi:10.1016/S01406736(07)61242-2.

Masten, A.S., Burt, K.B., Roisman, G.I., Obradović, J., Long, J.D., and Tellegen, A. (2004). Resources and resilience in the transition to adulthood: Continuity and change. Development and Psychopathology 16(4): 1071-1094. doi:10.1017/ S0954579404040143.

Mokdad, A.H., Forouzanfar, M.H., Daoud, F., El Bcheraoui, C., Moradi-Lakeh, M., Khalil, I., Afshin, A., Tuffaha, M., Charara, R., and Barber, R.M., et al. (2016). Health in times of uncertainty in the eastern Mediterranean region, 1990-2013: A systematic analysis for the Global Burden of Disease Study 2013. The Lancet Global Health 4(10): e704-e713. doi:10.1016/S2214-109X(16)30168-1.

Mokdad, A.H., Jaber, S., Aziz, M.I.A., AlBuhairan, F., AlGhaithi, A., AlHamad, N.M., Al-Hooti, S.N., Al-Jasari, A., AlMazroa, M.A., AlQasmi, A.M., Alsowaidi, S., Asad, M., Atkinson, C., Badawi, A., Bakfalouni, T., Barkia, A., Biryukov, S., El Bcheraoui, C., Daoud, F., Forouzanfar, M.H., Gonzalez-Medina, D., Hamadeh, R.R., Hsairi, M., Hussein, S.S., Karam, N., Khalifa, S.E.A.H., Khoja, T.A.M., Lami, F., Leach-Kemon, K., Memish, Z.A., Mokdad, A.A., Naghavi, M., Nasher, J., Qasem, M.B.H., Shuaib, M., Thani, A.A.M.A., Thani, M.H.A., Zamakhshary, M., Lopez, A.D., and Murray, C.J.L. (2014). The state of health in the Arab world, 1990-2010: An analysis of the burden of diseases, injuries, and risk factors. The Lancet 383(9914): 309-320. doi:10.1016/S01406736(13)62189-3.

Mortimer, J.T., Zimmer-Gembeck, M.J., Holmes, M., and Shanahan, M.J. (2002). The process of occupational decision making: Patterns during the transition to adulthood. Journal of Vocational Behavior 61(3): 439-465. doi:10.1006/jvbe.2002.1885.

Moussa, S., Kholy, M.E., Enaba, D., Salem, K., Ali, A., Nasreldin, M., Gabal, M., Emadeldin, M., and Moselhy, H.F. (2015). Impact of political violence on the mental health of school children in Egypt. Journal of Mental Health 24(5): 289293. doi:10.3109/09638237.2015.1019047.

Murray, C.J.L., Vos, T., Lozano, R., Naghavi, M., Flaxman, A.D., Michaud, C., Ezzati, M., Shibuya, K., Salomon, J.A., Abdalla, S., Aboyans, V., Abraham, J., 
Ackerman, I., Aggarwal, R., Ahn, S.Y., Ali, M.K., AlMazroa, M.A., Alvarado, M., Anderson, H.R., Anderson, L.M., Andrews, K.G., Atkinson, C., Baddour, L.M., Bahalim, A.N., Barker-Collo, S., Barrero, L.H., Bartels, D.H., Basáñez, M.-G., Baxter, A., Bell, M.L., Benjamin, E.J., Bennett, D., Bernabé, E., Bhalla, K., Bhandari, B., Bikbov, B., Abdulhak, A.B., Birbeck, G., Black, J.A., Blencowe, H., Blore, J.D., Blyth, F., Bolliger, I., Bonaventure, A., Boufous, S., Bourne, R., Boussinesq, M., Braithwaite, T., Brayne, C., Bridgett, L., Brooker, S., Brooks, P., Brugha, T.S., Bryan-Hancock, C., Bucello, C., Buchbinder, R., Buckle, G., Budke, C.M., Burch, M., Burney, P., Burstein, R., Calabria, B., Campbell, B., Canter, C.E., Carabin, H., Carapetis, J., Carmona, L., Cella, C., Charlson, F., Chen, H., Cheng, A.T.-A., Chou, D., Chugh, S.S., Coffeng, L.E., Colan, S.D., Colquhoun, S., Colson, K.E., Condon, J., Connor, M.D., Cooper, L.T., Corriere, M., Cortinovis, M., de Vaccaro, K.C., Couser, W., Cowie, B.C., Criqui, M.H., Cross, M., Dabhadkar, K.C., Dahiya, M., Dahodwala, N., Damsere-Derry, J., Danaei, G., Davis, A., Leo, D.D., Degenhardt, L., Dellavalle, R., Delossantos, A., Denenberg, J., Derrett, S., Des Jarlais, D.C., Dharmaratne, S.D., Dherani, M., Diaz-Torne, C., Dolk, H., Dorsey, E.R., Driscoll, T., Duber, H., Ebel, B., Edmond, K., Elbaz, A., Ali, S.E., Erskine, H., Erwin, P.J., Espindola, P., Ewoigbokhan, S.E., Farzadfar, F., Feigin, V., Felson, D.T., Ferrari, A., Ferri, C.P., Fèvre, E.M., Finucane, M.M., Flaxman, S., Flood, L., Foreman, K., Forouzanfar, M.H., Fowkes, F.G.R., Fransen, M., Freeman, M.K., Gabbe, B.J., Gabriel, S.E., Gakidou, E., Ganatra, H.A., Garcia, B., Gaspari, F., Gillum, R.F., Gmel, G., Gonzalez-Medina, D., Gosselin, R., Grainger, R., Grant, B., Groeger, J., Guillemin, F., Gunnell, D., Gupta, R., Haagsma, J., Hagan, H., Halasa, Y.A., Hall, W., Haring, D., Haro, J.M., Harrison, J.E., Havmoeller, R., Hay, R.J., Higashi, H., Hill, C., Hoen, B., Hoffman, H., Hotez, P.J., Hoy, D., Huang, J.J., Ibeanusi, S.E., Jacobsen, K.H., James, S.L., Jarvis, D., Jasrasaria, R., Jayaraman, S., Johns, N., Jonas, J.B., Karthikeyan, G., Kassebaum, N., Kawakami, N., Keren, A., Khoo, J.-P., King, C.H., Knowlton, L.M., Kobusingye, O., Koranteng, A., Krishnamurthi, R., Laden, F., Lalloo, R., Laslett, L.L., Lathlean, T., Leasher, J.L., Lee, Y.Y., Leigh, J., Levinson, D., Lim, S.S., Limb, E., Lin, J.K., Lipnick, M., Lipshultz, S.E., Liu, W., Loane, M., Ohno, S.L., Lyons, R., Mabweijano, J., MacIntyre, M.F., Malekzadeh, R., Mallinger, L., Manivannan, S., Marcenes, W., March, L., Margolis, D.J., Marks, G.B., Marks, R., Matsumori, A., Matzopoulos, R., Mayosi, B.M., McAnulty, J.H., McDermott, M.M., McGill, N., McGrath, J., Medina-Mora, M.E., Meltzer, M., Memish, Z.A., Mensah, G.A., Merriman, T.R., Meyer, A.-C., Miglioli, V., Miller, M., Miller, T.R., Mitchell, P.B., Mock, C., Mocumbi, A.O., Moffitt, T.E., Mokdad, A.A., Monasta, L., Montico, M., Moradi-Lakeh, M., Moran, A., 
Morawska, L., Mori, R., Murdoch, M.E., Mwaniki, M.K., Naidoo, K., Nair, M.N., Naldi, L., Narayan, K.M.V., Nelson, P.K., Nelson, R.G., Nevitt, M.C., Newton, C.R., Nolte, S., Norman, P., Norman, R., O’Donnell, M., O’Hanlon, S., Olives, C., Omer, S.B., Ortblad, K., Osborne, R., Ozgediz, D., Page, A., Pahari, B., Pandian, J.D., Rivero, A.P., Patten, S.B., Pearce, N., Padilla, R.P., PerezRuiz, F., Perico, N., Pesudovs, K., Phillips, D., Phillips, M.R., Pierce, K., Pion, S., Polanczyk, G.V., Polinder, S., Pope III, C.A., Popova, S., Porrini, E., Pourmalek, F., Prince, M., Pullan, R.L., Ramaiah, K.D., Ranganathan, D., Razavi, H., Regan, M., Rehm, J.T., Rein, D.B., Remuzzi, G., Richardson, K., Rivara, F.P., Roberts, T., Robinson, C., De Leòn, F.R., Ronfani, L., Room, R., Rosenfeld, L.C., Rushton, L., Sacco, R.L., Saha, S., Sampson, U., SanchezRiera, L., Sanman, E., Schwebel, D.C., Scott, J.G., Segui-Gomez, M., Shahraz, S., Shepard, D.S., Shin, H., Shivakoti, R., Silberberg, D., Singh, D., Singh, G.M., Singh, J.A., Singleton, J., Sleet, D.A., Sliwa, K., Smith, E., Smith, J.L., Stapelberg, N.J., Steer, A., Steiner, T., Stolk, W.A., Stovner, L.J., Sudfeld, C., Syed, S., Tamburlini, G., Tavakkoli, M., Taylor, H.R., Taylor, J.A., Taylor, W.J., Thomas, B., Thomson, W.M., Thurston, G.D., Tleyjeh, I.M., Tonelli, M., Towbin, J.A., Truelsen, T., Tsilimbaris, M.K., Ubeda, C., Undurraga, E.A., van der Werf, M.J., van Os, J., Vavilala, M.S., Venketasubramanian, N., Wang, M., Wang, W., Watt, K., Weatherall, D.J., Weinstock, M.A., Weintraub, R., Weisskopf, M.G., Weissman, M.M., White, R.A., Whiteford, H., Wiebe, N., Wiersma, S.T., Wilkinson, J.D., Williams, H.C., Williams, S.R., Witt, E., Wolfe, F., Woolf, A.D., Wulf, S., Yeh, P.-H., Zaidi, A.K., Zheng, Z.-J., Zonies, D., and Lopez, A.D. (2012). Disability-Adjusted Life Years (DALYs) for 291 diseases and injuries in 21 regions, 1990-2010: A systematic analysis for the Global Burden of Disease Study 2010. The Lancet 380(9859): 2197-2223. doi:10.1016/S0140-6736(12)61689-4.

Obermeyer, C.M., Bott, S., and Sassine, A.J. (2015). Arab adolescents: Health, gender, and social context. Journal of Adolescent Health 57(3): 252-262. doi:10.1016/j.jadohealth.2015.01.002.

Patel, V., Flisher, A.J., Hetrick, S., and McGorry, P. (2014). Mental health of young people: A global public-health challenge. The Lancet 369(9569): 1302-1313. doi:10.1016/S0140-6736(07)60368-7.

Pisarik, C.T. and Shoffner, M.F. (2009). The relationship among work possible selves, socioeconomic position, and the psychological well-being of individuals in early adulthood. Journal of Career Development 35(3): 306-325. doi:10.1177/08948 45308327276 . 
Population Council (2010). Survey of young people in Egypt. Cairo: Population Council.

Raleigh, C., Linke, A., Hegre, H., and Karlsen, J. (2010). Introducing ACLED: An Armed Conflict Location and Event Dataset Special Data Feature. Journal of Peace Research 47(5): 651-660. doi:10.1177/0022343310378914.

Ramadan, N. and Sieverding, M. (2015). Civic engagement, political attitudes, and youth's visions for the future. In: Roushdy, R. and Sieverding, M. (eds.). Panel survey of young people in Egypt 2014: Generating evidence for policy, programs, and research. Cairo: Population Council.

Reynolds, J.R. and Baird, C.L. (2010). Is there a downside to shooting for the stars? Unrealized educational expectations and symptoms of depression. American Sociological Review 75(1): 151-172. doi:10.1177/0003122409357064.

Roudi-Fahimi, F. and Kent, M.M. (2007). Challenges and opportunities: The population of the Middle East and North Africa. Population Bulletin 62(2): 1-20.

Roushdy, R. and Selwaness, I. (2015). Young people's labor market outcomes during a period of transition. In: Roushdy, R. and Sieverding, M. (eds.). Panel survey of young people in Egypt 2014: Generating evidence for policy, programs, and research. Cairo: Population Council.

Roushdy, R. and Sieverding, M. (2015). Panel survey of young people in Egypt 2014: Generating evidence for policy, programs, and research. Cairo: Population Council.

Sadler, K. and Gupta, N. (2014). Adolescent global health. In: Gupta, N., Nelson, B.D., Kasper, J., and Hibberd, P.L. (eds.). The MassGeneral hospital for children handbook of pediatric global health. New York: Springer: 121-137. doi:10.1007/978-1-4614-7918-5_10.

Salehi-Isfahani, D., Hassine, N.B., and Assaad, R. (2013). Equality of opportunity in educational achievement in the Middle East and North Africa. The Journal of Economic Inequality 12(4): 489-515. doi:10.1007/s10888-013-9263-6.

Salem, R. (2015). Changes in the institution of marriage in Egypt from 1998 to 2012. In: Assaad, R. and Krafft, C. (eds.). The Egyptian labor market in an era of revolution. Oxford: Oxford University Press: 162-181. doi:10.1093/acprof:oso/ 9780198737254.003.0009. 
Salem, R. (2016). The gendered effects of labour market experiences on marriage timing in Egypt. Demographic Research 35(11): 283-314. doi:10.4054/DemRes. 2016.35.11.

Scholte, W.F., Verduin, F., van Lammeren, A., Rutayisire, T., and Kamperman, A.M. (2011). Psychometric properties and longitudinal validation of the self-reporting questionnaire (SRQ-20) in a Rwandan community setting: A validation study. BMC Medical Research Methodology 11: 116. doi:10.1186/1471-2288-11-116.

Schulenberg, J., O’Malley, P.M., Bachman, J.G., and Johnston, L.D. (2005). Early adult transitions and their relation to well-being and substance use. In: Furstenberg, F.F., Rumbaut, R., and Settersten, R. (eds.). On the frontier of adulthood: Theory, research, and public policy. Chicago: University of Chicago Press: 417453. doi:10.7208/chicago/9780226748924.003.0013.

Schulenberg, J.E., Sameroff, A.J., and Cicchetti, D. (2004). The transition to adulthood as a critical juncture in the course of psychopathology and mental health. Development and Psychopathology 16(4): 799-806. doi:10.1017/S0954579404 040015.

Shanahan, M.J. (2000). Pathways to adulthood in changing societies: Variability and mechanisms in life course perspective. Annual Review of Sociology 26: 667692. doi:10.1146/annurev.soc.26.1.667.

Sieverding, M. and Hassan, R. (2016). 'Her future is marriage': Young people's attitudes towards gender roles and the gender gap in Egypt. Cairo: Population Council.

Singerman, D. (2007). The economic imperatives of marriage: Emerging practices and identities among youth in the Middle East. Washington, D.C.: Wolfensohn Center for Development and Dubai School of Government (Middle East Youth Initiative working paper, No. 6).

United Nations Department of Economic and Social Affairs (2015). Definition of youth [electronic resource]. New York: UNDESA. http://www.un.org/esa/socdev/ documents/youth/fact-sheets/youth-definition.pdf.

United Nations Department of Economic and Social Affairs, Population Division (2015). World population prospects: The 2015 revision, DVD edition. New York: UNDESA.

Urdal, H. (2006). A clash of generations? Youth bulges and political violence. International Studies Quarterly 50(3): 607-629. doi:10.1111/j.1468-2478.2006. 00416.x. 
Vizcarra, B., Hassan, F., Hunter, W.M., Munoz, S.R., Ramiro, L., and De Paula, C.S. (2004). Partner violence as a risk factor for mental health among women from communities in the Philippines, Egypt, Chile, and India. Injury Control and Safety Promotion 11(2): 125-129. doi:10.1080/15660970412331292351.

Vuolo, M., Staff, J., and Mortimer, J.T. (2012). Weathering the great recession: Psychological and behavioral trajectories in the transition from school to work. Developmental Psychology 48(6): 1759-1773. doi:10.1037/a0026047.

Whiteford, H.A., Degenhardt, L., Rehm, J., Baxter, A.J., Ferrari, A.J., Erskine, H.E., Charlson, F.J., Norman, R.E., Flaxman, A.D., Johns, N., Burstein, R., Murray, C.J., and Vos, T. (2013). Global burden of disease attributable to mental and substance use disorders: Findings from the Global Burden of Disease Study 2010. The Lancet 382(9904): 1575-1586. doi:10.1016/S0140-6736(13)61611-6.

World Bank (2016). World development indicators [electronic resource]. Washington, D.C.: World Bank. http://data.worldbank.org/data-catalog/world-developmentindicators. doi:10.1371/journal.pone.0152613.

World Health Organization (2000). Women's mental health: An evidence based review. Geneva: World Health Organization.

World Health Organization (2011). Strategy for mental health and substance abuse in the Eastern Mediterranean Region 2012-2016. Geneva: World Health Organization. http://www.emro.who.int/mental-health/strategy/.

World Health Organization (2014). Mental health: A state of well-being [electronic resource]. Geneva: World Health Organization. http://www.who.int/features/ factfiles/mental_health/en/. 